Portland State University

PDXScholar

11-6-1992

\title{
A Comparative Media Study of How AIDS-Related News is Reported in Mainstream and Alternative Presses
}

Robert Eugene Schlick

Portland State University

Follow this and additional works at: https://pdxscholar.library.pdx.edu/open_access_etds

Part of the Speech and Rhetorical Studies Commons

Let us know how access to this document benefits you.

\section{Recommended Citation}

Schlick, Robert Eugene, "A Comparative Media Study of How AIDS-Related News is Reported in Mainstream and Alternative Presses" (1992). Dissertations and Theses. Paper 4627.

https://doi.org/10.15760/etd.6511

This Thesis is brought to you for free and open access. It has been accepted for inclusion in Dissertations and Theses by an authorized administrator of PDXScholar. Please contact us if we can make this document more accessible: pdxscholar@pdx.edu. 
AN ABSTRACT OF THE THESIS OF Robert Eugene schlick for the Master of Science in Speech Communication presented November 6,1992

Title: A Comparative Media study of How AIDS-Related News is Reported in Mainstream and Alternative Presses.

APPROVED BY THE MEMBERS OF THE THESIS COMMITTEE:
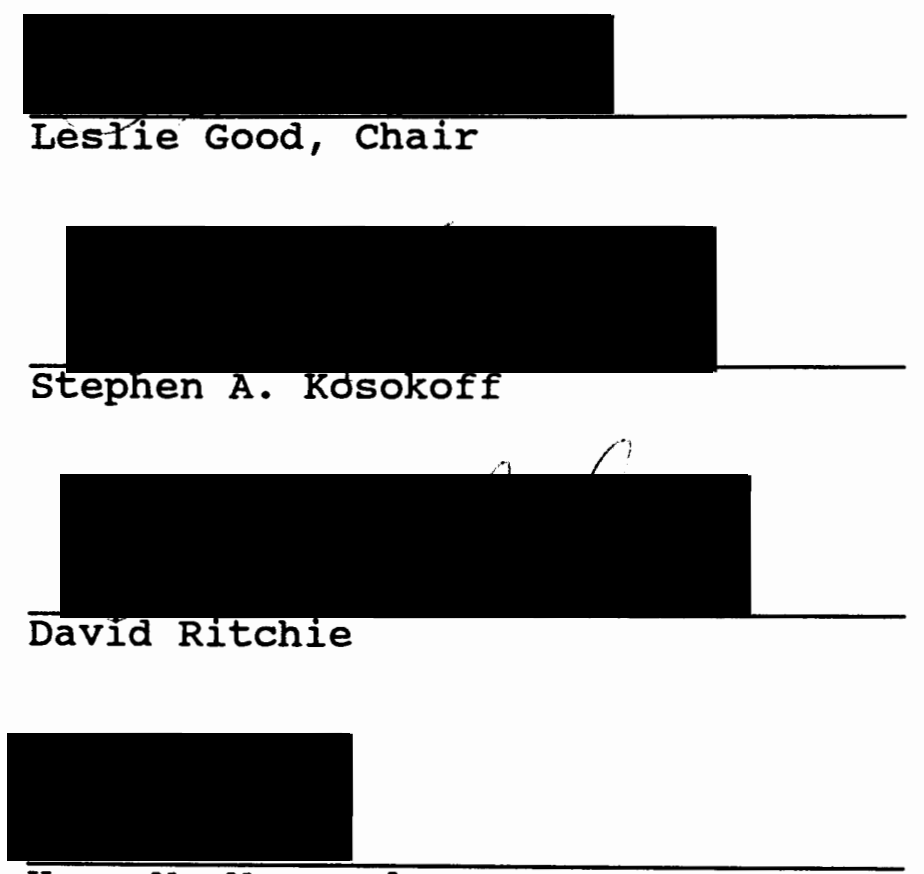

Hugo M. Maynard

This thesis examines the reporting of AIDS-related news in both mainstream and alternative newspapers. This research suggests that mainstream newspapers, such as the 
New York Times, frame news stories in certain ways. specifically, this study suggests that news about AIDS will be framed in ways which trivialize and/or marginalize those most affected by AIDS. The thesis also posits that the mainstream press will frame AIDS-related news in ways which support their own interests. Additionally, this research suggests that alternative presses, such as the Advocate, will frame their reporting of AIDS-related news in ways which support their interests.

The mainstream newspaper articles for this study were taken from the New York Times, and the oregonian. The alternative press articles were taken from the Advocate, the New York Native, Christopher street, outlook, and the San Francisco Bay Area Reporter. The news stories focus on four individuals: Magic Johnson, Rock Hudson, Kimberly Bergalis, and Mark Woodley.

The results of this thesis reveal that some mainstream reporting of AIDS-related news is framed in ways which trivialize and/or marginalize those affected by AIDS. The study also shows that the alternative presses frame reporting of AIDS-related news in ways which not only support their interests but in ways which appear to react to the reporting of the mainstream presses. Finally, there is evidence of hegemony as an underlying principle for the way news about AIDS is framed. 
A COMPARATIVE MEDIA STUDY OF HOW AIDS-RELATED NEWS IS REPORTED IN MAINSTREAM AND ALTERNATIVE PRESSES

by

ROBERT EUGENE SCHLICK

A thesis submitted in partial fulfillment of the requirements for the degree of

MASTER OF SCIENCE

in

SPEECH COMMUNICATION

Portland State University

1993 
TO THE OFFICE OF GRADUATE STUDIES:

The members of the Committee approve the thesis of Robert Eugene Schlick presented November 6, 1992 .

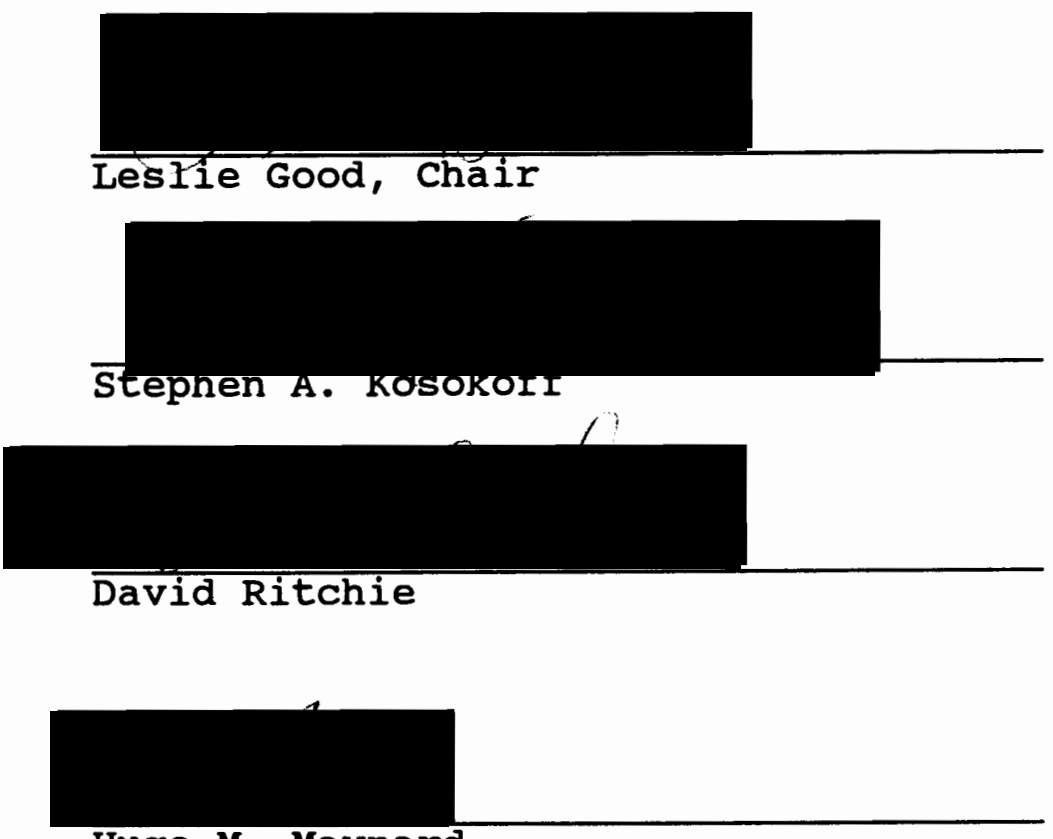

Hugo M. Maynard

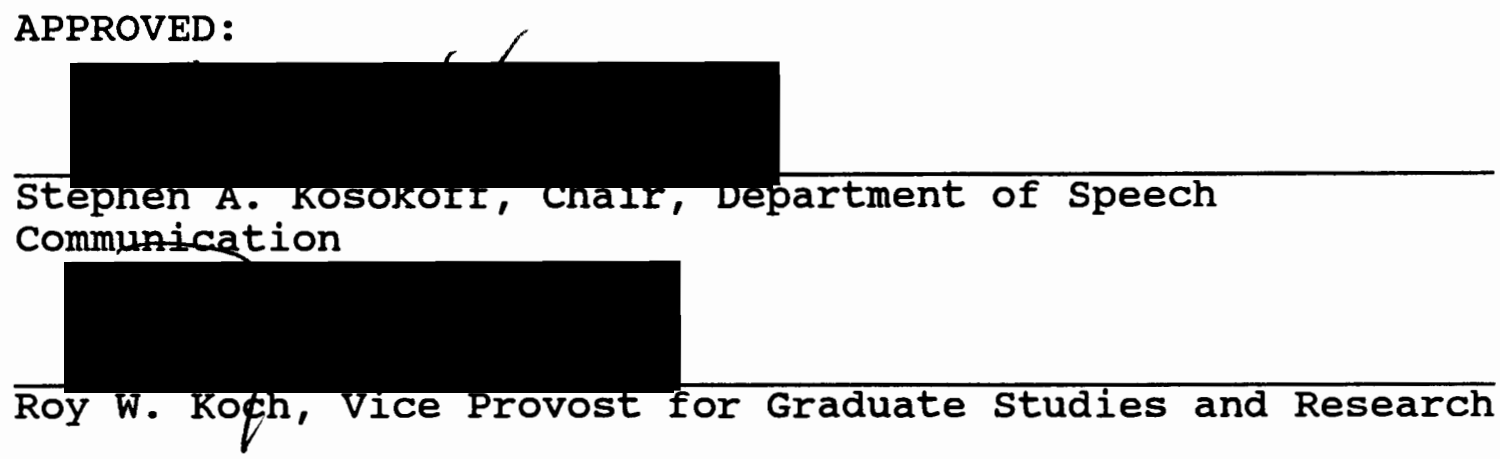


TABLE OF CONTENTS

PAGE

CHAPTER

I INTRODUCTION . . . . . . . . . . . . . . 1

II THEORETICAL BACKGROUND . . . . . . . . . 10

Communication Research . . . . . . . . 10

Hegemony and the Media . . . . . . . . . 14

News Reporting and AIDS. . . . . . . . . 17

News Framing

Summary . . . . . . . . . . . . . . . 20

III PROCEDURES • . . . . . . . . . . . . . . 21

Media Sources . . . . . . . . . . 22

Mainstream Newspapers

Alternative Newspapers

Sampling strategy . . . . . . . . . 25

Categories of News

Framing Devices . . . . . . . . . 29

Interpretation. . . . . . . . . . 31

The Role of Interpretation

IV NEWS FRAMING . . . . . . . . . . . . . 34

Magic Johnson . . . . . . . . . . 34

Rock Hudson . . . . . . . . . . 45

Summary of Findings Johnson/Hudson . • 54

Other AIDS-Related News . . . . . . 56 
Kimberly Bergalis

Mark Woodley

Chapter Summary . . . . . . . . . 64

V INTERPRETATION • . . . . . . . . . . 65

The Language of AIDS . . . . . . 66

The Gay Rights Movement . . . . . . 69

Hegemony and the Press . . . . . . 75

Conclusions . . . . . . . . . . 78

REFERENCES • • • • • • • • • • • • • • • • • • • 81 
CHAPTER I

\section{INTRODUCTION}

In the late 1970's New York physicians began recognizing patterns of disease among young gay men. At the same time in San Francisco, a handful of gay men were seeking medical aid for a variety of uncommon ailments. Concern with these developments was essentially limited to the medical community. But the problem did not go away, and in the early 1980's reports of a deadly new disease, possibly a virus, began to surface in the American news media. Initially, little was known about the illness and concern was still limited. Then, in 1981, reports claimed that the disease was a virus which suppressed the immune system. At least 60 cases were reported, but health officials did not know exactly what the illness was, how it spread, or how to treat it. However, officials did know that the disease was spreading exponentially. In late July of 1982, the name Acquired Immune Deficiency Syndrome (AIDS) was given to the disease, and by the end of 1982, in the United States, 1,285 cases were reported to the Centers for Disease Control (Couturie, Epstein, \& Friedman, 1989; Shilts, 1988). 
In 1983, new data relating to AIDS surfaced almost daily, yet the media largely ignored the growing problem. There were now 3,933 confirmed cases, and AIDS was thought to be a fatal disease. AIDS was also labeled a "gay disease" because it struck so many gay men, and the virus was linked to IV drug users and recipients of some blood transfusions. The number of people with AIDS kept increasing at an alarming rate: by $1984,9,915$ cases were reported; in $1986,31,452$ cases were reported; and by 1989, the number of reported cases of AIDS passed the 100,000 mark. At this point 59,000 people had died, more than the number of Americans who died in the Vietnam War (Couturie et al., 1989; Shilts, 1988).

It has now been over a decade since the onset of AIDS and no cure for the disease is in sight. The oncequestioned predictions of hundreds of thousands of deaths in the United states and millions of deaths worldwide are no longer speculative, but are becoming reality. In 1992, AIDS is not considered a rare disease, and, in fact, most Americans know something about AIDS and AIDS prevention.

The AIDS epidemic is clearly a significant social event for Americans. In light of the growing death toll, it would seem that the social response to AIDS would be loud and clear. However, there are more indications of social denial than social acceptance. In addressing concerns about the safety of the general population, Congressman William 
Dannemeyer stated that, "AIDS is a virus and viruses do not have civil rights" (McCuen, 1987, p. 120).

In the mid-80's, media attention to AIDS began to wane. Recommendations for massive public education, coordination of research, and calls for increased funding were largely ignored by the press. But celebrity cases, schoolchildren with AIDS, laboratory breakthroughs, and reports of AIDS spreading among heterosexuals received front-page attention (Shilts, 1988). In 1987, the United States initiated a national AIDS education campaign. The U.S. was one of the last developed nations of the world to respond to AIDS with a formal education plan (Couturie et al., 1989). And as recently as May of 1991, the federal government halted a plan to allow people with AIDS to enter the United states from foreign countries (De witt, 1991).

Why then does it appear that American society, in general, is turning its back on the AIDS epidemic? The answer, in part, lies in the fact that people with AIDS in this society are not only afflicted with a disease, but also are subject to the effects of membership in marginal groups. AIDS, for the most part, afflicts people who are already socially separated from the "general population" in some way:

AIDS... is an inhumane disease. Its virus fastens almost unerringly on humans already affected by special social and physical vulnerability..... It invades the bodies of the drug addicted, whose will to resist has already been captured by their habit. It massacres the population of male 
homosexuals, whose freedoms are already threatened by prejudice. AIDS seems to seek out as its victims the weakest and the already victimized (Juengst \& Koenig, 1989, p. xi).

Within the marginal groups whose members are afflicted with AIDS, gay males statistically and socially stand out from the other groups. Now that the blood supply is "protected," hemophilliacs rarely contract the virus. Predictions of widespread infection among heterosexuals is not yet seen in data reported by the media. And IV drug users are so deeply marginalized in our society that they, at least as reported by popular media, are merely statistics occasionally reported on the nightly news (Juengst and Koenig, 1989).

The statistics relating to gay men and AIDS are clear. Since the beginning of the epidemic, homosexual men have made up at least three-quarters of the cases. It is important to note that gay men are members of a stigmatized group that is one of many scapegoats for a frightened society (Juengst \& Koenig, 1989). In suggesting that the government's response to AIDS was shaped by the fact that gay men are its primary victims, Rep. Henry Waxman is quoted as saying, "It is clear that if this disease were hitting members of the American Legion or Chamber of Commerce, Ronald Reagan couldn't ask for more money fast enough" (Darsey, 1991, p. 56). Additionally, Juengst and Koenig (1989) assert that the metaphor of "otherness" is pervasive in discussions about the disease. The image of AIDS has 
been sustained as a problem for "them." Margaret Heckler, Health and Human Services Secretary, illustrated this by stating, "...we must conquer AIDS as well before it...threatens the health of our general population" ( $p$. 37). Members of the gay community expressed distress with this statement, claiming they were part of the general population.

To better understand AIDS, the disease, it is helpful to consider the people who may be further marginalized by the illness. In this instance the marginal group, gay men, must be examined in the context of the gay rights movement. The two social phenomena, the gay rights movement and AIDS, cannot be separated. That is, AIDS has had a significant effect on the movement, and the movement, since the early $1980^{\prime} \mathrm{s}$ has been fueled by AIDS.

A major source of information about AIDS and social movements like the gay rights movement in the United States is the news media. But the media were slow to start their coverage of the disease and media attention to AIDS has experienced numerous increases and decreases (see Diamond, 1990; Kinsella, 1988; Stein, 1988). Two of the most significant increases in American media reporting of AIDS came with the death of actor Rock Hudson in 1985 (Kinsella, 1989), and more recently with the public announcement of basketball star Magic Johnson that he is infected with HIV, the virus that causes AIDS (Gallagher, 1991). 
Kinsella (1989) suggests that the slow start in news reporting and the rise and fall of media interest in AIDS can be linked to the group that was first affected by AIDS, gay men. Unlike the Tylenol contamination incident, which threatened every American, or Legionnaire's disease, which struck white, middle-aged men, AIDS affected social outcasts, gays. In studying the media coverage of AIDS, Kinsella found that many editors decided that news about homosexuals was of little interest to their readers. Additionally, the later development linking AIDS and IV drug users, another group of social outcasts, was not seen as having the potential to increase media appeal concerning AIDS. Furthermore, the increases in media activity associated with specific events in the AIDS crisis can be linked to personalities with whom the heterosexual community can identify -- for instance, Rock Hudson (see Kinsella, 1989; Panem, 1988; Shilts, 1988), and Magic Johnson (Gallagher, 1991).

The mainstream American news media organizations (including large daily newspapers, network and cable news companies, and weekly news magazines) have been an important source of information regarding AIDS. I define mainstream media as national news organizations whose reporting is accessible to, and directed at, mass audiences. However, mainstream media have not been the only media source of important information; alternative media have also been a 
vital source of information for the audiences they serve. I define alternative media as news organizations whose reporting is directed to specialized audiences. In 1988, Jamieson and Campbell described specialized media as segmented or minority media, and cited Ebony, Guns and Ammo, and Savvy as examples of specialized media. It is relevant to point out the distinctions between mainstream and alternative media because of the potential differences in what is reported and when it is reported. For instance, the New York Native, an alternative paper serving the gay community, was the first American media source to report news concerning AIDS, and the Native continued to provide coverage directed at its gay readers long before the mainstream media covered the story (see Kinsella, 1989; Leishman, 1989; shilts, 1988).

Kinsella (1989) states that AIDS is now a staple item in the news and a part of the American consciousness. Kinsella asserts that much of the credit for news reporting about AIDS lies with journalists who relied on their own experiences with AIDS as a motivating factor in deciding to report AIDS-related news. These journalists include vince Coppola from Newsweek, whose brother was gay and had AIDS, and Chuck ortleb, publisher of the New York Native, whose friends were dying by the scores.

It is relevant to point out several experiences in the AIDS crisis that have ultimately led me to this study. In 
addressing the role of the rhetorical critic, Foss (1989) states that "the critic brings to the critical task particular values and experiences, and these are reflected in how the critic sees and writes about the artifact" ( $p$. 25). Furthermore, Gitlin (1980) examined how the New York Times and CBS framed news reports on the activities of students for a Democratic society. Gitlin describes a feeling of "disjuncture" after working within the social movement, actively participating in the events reported, and then seeing the media define and characterize the movement as something else. Gitlin states that "this continuing experience of disjuncture gave me my agenda for research" $(\mathrm{p} .17)$

Looking back at my own experiences, two key elements have persistently raised questions in my mind over the past decade. First, in the early $1980^{\prime} \mathrm{s}$, the information I received about the new "gay cancer" came primarily from rumors. As I remember, these rumors were generated from scant reporting by the mainstream media. I, along with tens of thousands of gay men across the nation, sought answers to questions about the disease by watching the nightly news and reading the newspapers. Our questions had to be answered; we wanted to know if we would also die. However, days and sometimes weeks would go by with virtually no media reporting. But the picture quickly changed when the alternative media -- specifically, national and local gay publications - 
- began covering the story. Suddenly, many gays received news about the disease that was directed at them.

As friends and loved ones died, I sought all the information I could acquire. I became an avid reader of AIDS-related news from both mainstream and alternative sources. My second key observation was that what I read in the mainstream press was not necessarily what I would find in the alternative press, and vice versa. More recently, as a student of communication, I have made another observation: the discipline has been slow to begin study of the endless variety of communication events that surround AIDS.

As Kinsella makes clear in his analysis of AIDS and the media, reporting news related to AIDS is now fairly routine in most news organizations. However, the potential for bias and inaccuracies in reporting AIDS continues to exist. The announcement in 1991 by Magic Johnson that he has the HIV infection provides an important contemporary example for an analysis of media reporting of AIDS. Johnson's announcement caused a significant increase in the amount of media reporting (Gallagher, 1991) and a corresponding response in the alternative media. In addition to the reporting surrounding Johnson's disclosure, I examined how news related to a similar disclosure by Rock Hudson was reported six years earlier. Finally, I examined how other AIDSrelated news was reported in the weeks following Johnson's announcement. 
CHAPTER II

THEORETICAL BACKGROUND

COMMUNICATION RESEARCH

A comprehensive examination of communication research in the 1980's reveals a general absence of work that is related to the broad topic of AIDS and the communication which surrounds the disease. The absence of published research may be due, in part, to the long lead-time involved in academic research. However, in December, 1990, Communication Research devoted an entire issue of the journal to the AIDS crisis. Introducing the issue, Norton (1990) states that "although the most obvious role that the communication scholar can play is in the area of prevention of HIV infection, scholars and activists can study and work in many areas" (p. 734). The special issue includes a discussion concerning the communicative process of talking about AIDS among sexual partners (Cline, Freeman, \& Johnson 1990), a study of AIDS and the hemophiliac (Scheerhorn, 1990), and a discussion of the rhetoric of black urban adolescents and HIV education (Bowen \& Johnson, 1990). Additionally, in 1989, Gilder analyzed the process by which gay people see themselves in relation to the social construction of AIDS discourse, both as individuals and as a collective. 
In a recent study examining a thirteen-year period from 1977 to 1990, Darsey (1991) built on the results of his earlier analysis of gay rights rhetoric from 1948 to 1977 . The combined study makes observations about changes in the discourse of the gay rights movement over more than four decades. Darsey's rhetorical study employs the analytic tools of isolating catalytic events, determining rhetorical eras, and identifying value appeals within each era. Darsey defines catalytic events as "markers of rhetorical eras and partitions for rhetorical sampling" (p. 46). The AIDS crisis can be viewed as a catalytic event in the gay rights movement. Darsey states that "AIDS became the obsessive concern of gay rights activists, coloring all activity concerning the welfare of gay men and lesbians in the United states. AIDS presented the gay community with not only a public health crisis, but crises in the social, legal, and psychological spheres as well. AIDS catalyzed a shift in the rhetoric of the gay movement" (p. 55).

Thus, a catalytic event, like the AIDS crisis, can be seen as establishing the second component in Darsey's model, a rhetorical era. Finally, within rhetorical eras, Darsey uses value analysis, a content-analytic coding scheme of quantifying significant characteristics of discourse, to further identify important rhetoric found in the movement. Darsey's sample was newspaper editorials and opinion pieces from gay presses. 
Darsey's work provides significant grounding for the current work. Specifically, Darsey's study answers questions concerning identification of the gay rights movement as a social movement worthy of study, defining the AIDS crisis as a significant event in the movement, and identification of the gay press as an important source of rhetorical data. Darsey asserts that the gay rights movement is "a significant American social movement" ( $p$. 43.). Darsey also posits that studying the movement is useful for theory-building as the gay rights movement has no confusing antecedents. The movement has a well-defined point of origin. The relatively short history of the movement allows a complete study of its organizations, publications, and spokespeople, and archives of rhetorical records are available.

Many scholars, other than Darsey, have made generalizations that are applicable to the gay rights movement. Lucas (1980) asserts that scholars must explicate the changing discourse of a movement and examine how the discourse functions or helps to propel the movement or retard its evolution. Cathcart (1980) sees the emergence of a rhetoric and counter-rhetoric as an important element in the foundation of social movements. Finally, stewart (1980) delineates five general functions that might be applied to the rhetoric of social movements: transforming perceptions of history; transforming perceptions of society; prescribing 
courses of action; mobilizing for action; and sustaining the social movement.

As I have previously stated, in the first decade of the AIDS crisis relatively little communication research on AIDS was published. However, other disciplines have reached general conclusions that might be relevant. Sontag (1989) discusses AIDS and its metaphors; Kinsella (1989) examines media coverage of AIDS; Shilts (1988) provides an historical recounting of AIDS; and journalists, Diamond (1990), Brechner (1988), Dorfman (1987), Boulard (1989), and stein (1988) all provide critical analyses of AIDS and how it is reported. Beyond any established theoretical base, it seems obvious that the AIDS crisis is a significant event in the gay rights movement. Few American social movements have seen tens of thousands of its members die as the movement evolves.

Darsey (1991) establishes the gay presses (editorials and opinion pieces) as viable sources of rhetorical data by relying on gay publications for his sample. Shilts (1988) relies heavily on gay presses for his historical work, and Kinsella (1989) analyzes AIDS reporting by examining mainstream news sources like the New York Times and gay publications like the New York Native. I used alternative publications (in my study, gay publications), because gay people constitute the group that has been, and continues to be, the most affected by AIDS in America. Additionally, as 
I will establish, gay alternative publications have been, and continue to be, at the forefront of AIDS reporting. Perhaps most importantly, Darsey's conclusions reveal issues of domination, marginality, and hegemony in relation to the AIDS crisis and the gay rights movement. For instance, Darsey states that there is little faith that "left to its own devices, the government will look after the best interests of gay people" (p. 56) and that the government is not doing all it could with respect to AIDS. In referring to the decision of the American Psychiatric Association to remove the stigma of sickness from homosexuality in 1973, Darsey states that the APA's decision illustrates:

...the degree to which subcultures are dependent on the cultures of which they are a part, even on matters essential to defining the lines of demarcation between them. No amount of selfpersuasion regarding, in this case, the essential health of gay people could withstand widescale criticism as long as that criticism appeared to have the blessing of the psychological and psychiatric establishment. Dominant cultures have ultimate control over vehicles for legitimation, one of the key factors in defining dominance. (p.58)

\section{HEGEMONY AND THE MEDIA}

In defining what news is, Gitlin (1980) summarizes a synthesis of approaches composed by Gans (1979) and concludes that news-reporting organizations are influenced by pressures inside and outside the organization, and that the production of news is a system of power. However, 
Gitlin moves another step in his analysis of the "framing process and the media-movement relationship" (p. 251), and asserts that hegemony is a potential influence in media framing. Referring to Gramsci, Gitlin defines hegemony as "a ruling class's (or alliance's) domination of subordinate classes and groups through the elaboration and penetration of ideology (ideas and assumptions) into their common sense and everyday practice; it is systematic (but not necessarily or even usually deliberate) engineering of mass consent to the established order" (p. 253). Additionally, Gitlin states that "the more closely the concerns and values of social movements coincide with the concerns and values of elites in politics and in media, the more likely they are to become incorporated in the prevailing news frames" (p. 284). However, if the concerns of a social movement, such as the gay rights movement, do not coincide with the concerns and values of the elites, the social movement may be seen as a challenge to the hegemony of the dominant class. At this point the framing of news related to the movement will likely be unsympathetic, and may, in fact, show the movement and its members as illegitimate and marginal. This line of reasoning can easily be applied to media reporting of AIDSrelated news. Gays are perceived as being marginal participants taking part in a marginal social movement. The AIDS crisis, often perceived as "gay related" is just another aspect of a marginal lifestyle which challenges the 
hegemony of the dominant class (Kinsella, 1989; Diamond, 1990; Shilts, 1988; Rouilard, 1991; Gallagher, 1991). Gitlin (1987) explains that the process of hegemony goes beyond mere domination and is actually an unequal collaboration between those in power and those who are dominated. He says:

Absolute power coerces; hegemony persuades, coaxes, rewards, chastises. Absolute power forbids alternatives; hegemony organizes consent and allocates a certain limited social space to tailored alternatives....hegemony is the orchestration of the wills of the subordinates into harmony with the established order of power. (p. 241)

Gitlin's explanation of hegemony as unequal collaboration can be applied to groups outside the mainstream who seek representation in the media. Gross (1991) observed that the holders of power do not generally need to seek media visibility, and those at the bottom of power hierarchies will be kept in place, in part, through their invisibility. This "symbolic annihilation" of certain groups is constantly changing to exclude or include pointsof-view. Yet when a marginalized group does attain some visibility, the representation of the group will reflect the biases and interests of the elites. Gross states that these elites are "(mostly) white, (mostly) middle-aged, (mostly) male, (mostly) middle and upper-middle class, and entirely heterosexual (at least in public)" (p. 21). 
NEWS REPORTING AND AIDS

In presenting the theoretical foundation for this study, it is essential to address specific areas relating to news reporting, including the influence of news reporting and how the media have approached AIDS reporting. In developing a view of the media, (particularly television and to a lesser extent, newspapers) Jamieson and Campbell (1990) describe the media's influence on their audience, and state that "newsgatherers and news organizations are persuaders who shape our views of reality, who induce us to believe one thing rather than another" (p. 19).

The authors assume that all communication is reciprocal, jointly created by the source and the audience. The media have unique resources for communication and influence because of how we receive, perceive, and interact with them. Additionally, Jamieson and Campbell posit that mass-mediated messages cannot be separated from the economic and political systems in which they function. Jamieson and Campbell also state that news coverage influences us by defining what the different "sides" are in an issue, and what each "side" means. Also, themes used in news reporting provide continuity and help the audience make sense out of the news.

Gans, in his 1979 study of network news reporting and weekly news magazines, argues that one person's or group's order may be another's disorder, and that it is relevant to 
ask whose order is being valued in news reporting. Gans suggests that most of the routine, or orderly activities which appear in the news, are carried out by elected and appointed officials, whereas social and moral disorder news generally involves ordinary people. The news often supports those who abide by the enduring values. Furthermore, Gans argues that the news reflects a white male social order, and one that is middle-aged or old, and upper-class or uppermiddle-class.

Much of the literature relating to AIDS and the media is critical of the media's role in the AIDS crisis. Brecher (1988) is critical of newspaper and magazine coverage of the AIDS epidemic spreading rapidly into the heterosexual community. The conclusion of Brecher's essay is that much of the hysteria surrounding the spread of AIDS is based on "scare stories" aimed at the heterosexual population by the press. Brecher adds that the wrong public health message is being sent to the wrong recipients. Boulard (1989) examines AIDS coverage by a small-town newspaper that was faced with opposition from the community when AIDS articles appeared on page one. In asserting that AIDS received scant attention, even from major newspapers, until Rock Hudson died, the director of the American Press Institute stated that AIDS coverage was only strong when there was some breakthrough or "hot story." The attitude today is, "your papers will probably never cover a story bigger than AIDS" (stein, 1988, 
p. 45).

Journalism's slow start in recording the AIDS crisis is recounted by Kinsella (1989). Looking back at the early days of AIDS, Kinsella concludes that as long as the disease seemed to be affecting homosexuals and drug addicts, news organizations ignored it. Kinsella asserts that the New York Times is the national newspaper of record, and in that role the Times delayed in-depth reporting of AIDS in the early years of the crisis (see also, Gans, 1979; Gitlin, 1980; Panem, 1988; Shilts, 1988). Kinsella states that the Times is a powerful agenda-setter that made editorial decisions to not give AIDS substantial coverage. At the same time, Kinsella builds a more favorable case for alternative papers like the New York Native, stating that some of the most intensive, early reporting came from gay papers. In fact, Kinsella reports that when the Times finally changed its editorial policies concerning AIDS reporting in 1983 , many Times reporters read the Native to find out what was happening with the epidemic.

\section{News Framing}

Gitlin (1980) discusses media coverage of the activities of the students for a Democratic society (SDS) by the New York Times and CBS. The author shows how the news media defined frames for the SDS that eventually cast them as illegitimate. Gitlin defines media frames as "persistent patterns of cognition, interpretation, and presentation, of 
selection, emphasis, and exclusion, by which symbol-handlers routinely organize discourse, whether verbal or visual" ( $p$. 7). Gitlin further asserts that media frames organize the world for journalists and for the people who rely on their reports.

When the SDS marched on Washington in the spring of 1965, there was a shift in media attention, and SDS activity became big news. Gitlin (1980) asserts that the movement became amplified, and that certain themes, or framing devices, began to emerge including: trivialization; polarization; an emphasis on internal dissension; marginalization; disparagement by number; and disparagement of the movement's effectiveness.

\section{SUMMARY}

Darsey, Gitlin, and Kinsella all found evidence of hegemony in their research. These findings led me to the expectation that I would find evidence of hegemony in the framing of AIDS-related news in the mainstream press. Specifically, I predicted that the mainstream press, in presenting AIDS-related news, would use framing devices that include trivialization, marginalization, and disparagement by numbers. I also expected that the alternative presses would react to the framing devices used by the mainstream media and frame reporting of AIDS news in ways which support their own interests. 
CHAPTER III

PROCEDURES

The media are a primary source of information in our culture. We read newspapers, watch televised news programs, and read news magazines to learn what is happening in our world. In the early $1980^{\prime}$ s news stories about AIDS were being reported. At first little was known about the disease. However, as the AIDS crisis progressed the illness was labeled a "gay disease" because of the population it most affected in the United States. The connection between AIDS, a disease, and AIDS, a gay disease can be seen as a challenge to the interests of the dominant class (Kinsella, 1989). I will attempt to show that this information, that AIDS was primarily affecting gay men, was reinterpreted through hegemonic practices so that it was compatible with mainstream interests. One of the primary means of reinterpreting information so that it supports dominant interests is through the media. The purpose of this thesis is to examine how AIDS-related news is reported, and to see if hegemony is present in the reporting. 
MEDIA SOURCES

The design of this study was influenced, in part, by research conducted by Gitlin in 1980. In his study, Gitlin examined how news was reported about students for a Democratic Society, (SDS). The author shows how the news media established frames for the SDS that eventually cast them as illegitimate. Gitlin used the New York Times and CBS News as representative media sources for his research on SDS.

\section{Mainstream Newspapers}

I selected newspapers as the media source for this study because of the accessibility of papers and because they provide a permanent written record. Beyond the selection of newspapers as the media source, I separated the sources into two categories: mainstream and alternative presses. I define mainstream newspapers as national news organizations whose reporting is accessible to mass audiences. My primary mainstream newspaper source for this study is the New York Times. I chose the Times because it is commonly viewed as the voice of record for American news reporting (Kinsella, 1989). In addition to the Times' prominence in news reporting, it is also perhaps the best indexed newspaper in the nation, making it ideal for research. In addition to the New York Times, I chose the Oregonian, a Portland newspaper, as an additional mainstream 
media source. The inclusion of the oregonian provides a local perspective on reporting of AIDS-related news. Additionally, the choice of the oregonian provides an opportunity to compare reporting by the Times with a smaller, local newspaper.

\section{Alternative Newspapers}

The mainstream media have not been the only source for AIDS-related news; alternative press have also been an important source of information for the audiences they serve. I define alternative media as news organizations whose reporting is directed at specialized audiences. It is relevant to point out the distinctions between mainstream and alternative media because of the potential differences in what is reported and when it is reported. The alternative publications which I selected for this study are gay publications because gay people constitute the group that has been, and continues to be, the most affected by AIDS in America. Additionally, as I have established, gay publications have been, and continue to be, at the forefront of AIDS reporting. I have chosen gay presses as the comparison to mainstream presses because of the organization of, and news reporting by, the gay community in fighting AIDS. Other groups, for instance IV drug users and recipients of blood transfusions, are greatly affected by AIDS. However, these groups lack the alternative news reporting that the gay community has developed in recent 
years.

My alternative press selections include the Advocate, the New York Native, Christopher Street, outlook, and the San Francisco Bay Area Reporter. These publications are respectively a national news magazine, a local New York paper with national distribution, a national news and literary magazine, a Southern California magazine, and a San Francisco area news and entertainment paper. My alternative press selections include "news magazines" because there is no national, gay newspaper other than the Advocate which claims this distinction.

The inclusion of alternative presses in this study presented several problems. For instance, a portion of the study examines reporting of the disclosure by Magic Johnson of his HIV infection. News reports in the mainstream press were published within hours of Johnson's announcement. News reports of the announcement did not appear in alternative publications such as the Advocate for nearly a month. one possible explanation for the delay is that the alternative press organizations are not able to respond quickly to current events because many of them, such as the Advocate are published bi-weekly or monthly. Consequently, the dates of alternative press articles do not always coincide with the mainstream press articles. An additional problem in including alternative presses in this study is that the published articles are not all indexed. When indexes are 
available they are generally found only in larger metropolitan areas. And when pertinent articles can be located through a comprehensive index, back issues of publications may be impossible to find.

\section{SAMPLING STRATEGY}

We are now over a decade into the AIDS crisis and mainstream media coverage is frequent and available from many sources. AIDS-related news coverage includes a diversity of topics including: treatment issues, policy and funding issues, AIDS as a global issue, and the effect of AIDS on individuals' lives. From the beginning I have been most interested in researching how the media communicate information about individuals and AIDS. In late 1991, as I began this study, Magic Johnson made his public announcement concerning his HIV status. That event provided a timely opportunity to study the reporting of an individual who is also a celebrity. To contextualize the reporting of Johnson's disclosure, I looked back to the reporting of Rock Hudson's disclosure that he was dying from AIDS in 1985. The comparison of Hudson and Johnson provides an example of how AIDS reporting has changed, and how it has not changed in recent years.

To keep my sample current I chose to examine other reporting that was published in mainstream and alternative presses at the same time as Magic Johnson's announcement. 
Therefore, my sample of reporting on individuals includes stories which were written about Kimberly Bergalis and Mark Woodley. Bergalis is a Florida woman who allegedly contracted AIDS from her dentist, and woodley is an AIDSinfected resident of New York City who was denied a job as Santa Claus by Macy's department store. I included reporting about Bergalis and Woodley, noncelebrities, as a comparison to the reporting of two celebrities, Johnson and Hudson. Bergalis was essentially made famous through media reports of her struggle with AIDS. Woodley's story was reported over a short period of time by a limited number of publications. As I gathered data on Bergalis and Woodley from mainstream sources I attempted to find coverage which would also be reported by the alternative media. In addition to the news about Bergalis and Woodley appearing in the mainstream press, the alternative press reported both stories.

My primary means of locating appropriate data for this study was to read both mainstream and alternative newspapers. To supplement what I found I used an indexing service (InfoTrac) to locate reporting about Johnson which I might have otherwise missed. As I have previously stated, the New York Times index contained the most complete and available information I could find. I essentially searched for articles related to "AIDS the disease" and appropriate subheadings such as "AIDS patients," "AIDS individuals," and 
"Magic Johnson." By this method I was able to establish a representative sample of reporting about Johnson that was published in the Times.

I began data collection on November 8,1991 , the day Johnson made his announcement. The last article I examined about Johnson from the New York Times was dated December 29, 1991. The time period for this study roughly falls between November 8, 1991 and December 31, 1991, the period when most of the reporting about Johnson was published in the Times. An exception to this time period was the 1985 reporting on Rock Hudson's announcement. For the Hudson story I examined articles published between the first reports of his failing health until his death several months later. Reporting about Kimberly Bergalis began before news about Johnson was reported, but I included reporting about Bergalis that was published only during the November 8 to December 31 time period.

Because of accessibility problems and publishing schedules, some of the alternative press articles I use in this study do not fall within the November 8 to December 31 time period. For instance, some of the reporting about Kimberly Bergalis was published in the Advocate on september 10, 1991, and on January 6, 1992 in Christopher street. My primary alternative press data source was the Advocate. However, I had to rely on other alternative publications for some stories. For instance, the Advocate did not publish 
anything on the woodley story, but I was able to find articles in other alternative publications like the Bay Area Reporter, and the New York Native.

\section{Categories of News}

Tuchman (1978) identified at least two categories of news reporting: hard and soft news. These categories differentiate kinds of news content or subject matter. Hard news "concerns occurrences potentially available to analysis or interpretation, and consist of 'factual presentations' of occurrences deemed newsworthy," while soft news is defined as "feature or human-interest stories" (p.46). But these categories may overlap, making it difficult to decide if a story is hard or soft news. Tuchman adds that the same event may be treated as either a hard or soft news story by different reporters or editors.

The news stories I examined for this study illustrate the difficulty in distinguishing between hard and soft news. For instance, the majority of reporting relating to Magic Johnson's announcement appeared in the sports section of the New York Times and the oregonian. All of the stories report the fact that Johnson made his announcement. The Times published eight stories relating to Johnson in one day and all of the stories include the information that Johnson has HIV. Much of the remaining text of the stories in this study could be viewed as soft news. For instance, both the Times and the oregonian include text which discusses 
Johnson's, and earlier, Rock Hudson's sexuality. Throughout this study I refer to the news "reporting" that takes place in relation to the four individuals whose stories I examined. However, it is difficult to distinguish between hard and soft news reporting in most of the examples. Many of the stories contain an element of commentary that appears to be the opinion of the reporter or news writer. I base this statement on the fact that what is stated in the stories is seldom attributed to other sources. In the text of the study, I do not make a distinction between commentary and news reporting.

\section{FRAMING DEVICES}

After collecting articles on the four individuals I studied in this work, I identified framing devices that were used in reporting their stories. Again, Gitlin's 1980 work provided an example of appropriate framing devices. Gitlin defines frames as "principles of selection, emphasis and presentation composed of...tacit theories about what exists, what happens, and what matters" (p. 6). Gitlin states that "media frames, largely unspoken and unacknowledged, organize the world both for journalists who report it and, in some important degree, for us who rely on their reports" (p. 7). Frames guide newswriters when making decisions about what to include in a story, what not to include, and how to present what is published. Gitlin's research revealed certain 
themes or frames which include: trivialization (or the making light of movement language, dress, age, style, and goals); polarization (or emphasizing counterdemonstrations, and balancing the antiwar movement against other "extremist" groups); an emphasis on internal dissension; marginalization (or showing demonstrators to be deviant or unrepresentative); disparagement by numbers (or undercounting); and disparagement of the movement's effectiveness.

The framing devices Gitlin found in his study can appropriately be applied to other news reporting. However, Gitlin researched the framing of news related to a social movement. In the current study I am researching how news is framed about a disease. Therefore, I redefined three of Gitlin's identified framing devices which are most suited for this research: trivialization, marginalization, and disparagement by numbers. For the purposes of this study I define trivialization as making light of or minimizing what has occurred to-date in the AIDS crisis. I define marginalization as showing those affected by AIDS (people with AIDS, friends, family, and loved ones) as being on the outside or fringe of the mainstream or majority. Finally, I define disparagement by numbers as underreporting, an absence of reporting, or incorrect reporting of AIDS-related statistics.

In summary, my procedure for conducting the study portion of this thesis was to identify the individuals whose 
stories I would use and then locate the appropriate articles in both mainstream and alternative publications. I began with the New York Times by reading all of the articles about a specific individual, for instance, Magic Johnson. I then read all of the oregonian articles about Johnson, and proceeded to the alternative press articles on Johnson. I then returned to the Times and reread the articles, this time examining each piece for instances of the three framing devices based on my definitions of those frames.

\section{INTERPRETATION}

Beyond the identification of frames that are used in reporting news about AIDS, I was interested in interpreting what the use of these frames might mean. Gitlin (1980) again provided an example for how to proceed. Gitlin states that an analysis of mass media content must ask questions concerning framing of the news. These questions include: What is the frame? Why was this frame and not another used? What patterns are shared by the frames used in different events, different media, different places, and different moments? How do the news organizations regulate framing? And what difference do the frames make for the larger world? To focus the direction of my interpretation I chose to include only those questions which were most relevant to this study. Specifically, I ask what is the frame? And why was this frame and not another used? However, my 
interpretation also reveals the answer to the question, what difference do the frames make for the larger world?

The Role of Interpretation

In addition to providing a description of the rhetorical data I use, in this case newspaper articles, I have a responsibility to interpret the data. In completing this task I am unable to completely remove myself, my past experience and knowledge, from the interpretation. Foss (1989) states that:

The critic brings to the critical task particular values and experiences, and these are reflected in how the critic sees and writes about the artifact. Thus, two rhetorical critics may ask the same question about an artifact, use the same method to investigate it, and come up with different conclusions about it....the critic acknowledges subjectivity in the writing of the essay by presenting claims not as truth about reality but simply as one way of describing the artifact or one way of seeing reality. (p. 25)

As I have stated, I bring past experience with me as I approach the task of interpretation. This experience includes involvement in the movement for gay rights as well as personal involvement in the AIDS crisis. In describing the political nature of interpretation Mumby (1988) states that:

...the goal of interpretation is not to provide some absolute reading of a text which provides a definitive explication of the relationship between that text and the world it purports to describe. The goal is rather to draw attention to the process of interpretation itself, and to show how certain dominant readings become incorporated into texts, such that a certain view of the world is maintained and reproduced. (p. 160) 
Finally. the critic, as well as the reader of criticism, may face the ambiguous nature of interpretation. It is likely that no two interpretations or reading of the texts I use in this study would be the same. My goal in this research is not to provide the definitive interpretation of the texts I examined. Instead as Mumby suggests, my purpose is to draw attention to the process of interpretation itself, and specifically to draw attention to my unique interpretation of the texts. 
CHAPTER IV

NEWS FRAMING

MAGIC JOHNSON

On November 7, 1991, Earvin (Magic) Johnson announced in a nationally televised press conference that he is infected with HIV, the virus that causes AIDS. In the first decade of the AIDS crisis many thousands of people have discovered they have HIV, and many of those people have died from AIDS. The American news media have rarely given so much attention to an individual's struggle with HIV or AIDS. But Johnson's announcement gained the attention of national and international news organizations and created a flurry of media activity that was unprecedented in the AIDS crisis (Gallagher, 1991). Magic Johnson is more than a popular basketball player; he is one of the most accomplished players in basketball history. In a front-page, New York Times news story, Johnson is cited as a "gifted athlete," with worldwide popularity, who is "by far the most famous sports figure to be infected by the AIDS virus" (Stevenson, 1991, p. 1). Magic Johnson may be the most famous American to have announced his HIV status.

Johnson's announcement provides an opportunity to examine the framing of news related to the AIDS crisis by 
both the mainstream and alternative presses. Although my focus is on how the news is framed, specifically, through trivialization, marginalization, and disparagement by numbers, I will also discuss other aspects of news framing such as what is included or not included in the framing of AIDS reporting. Because of the attention given to Johnson's announcement by the American media, I will use the reporting surrounding that event as the basis of this study. However, to gain a more complete perspective of how news related to AIDS is framed, I will examine other instances of reporting as they apply. For example, it is of value to discuss the 1985 announcement by actor Rock Hudson that he had AIDS. In sum, my intention is to describe how the mainstream press framed the news of Johnson's announcement, and compare the reporting, or reaction to the reporting, by the alternative press. It is important to reiterate my intention to complete an interpretive analysis of not only the framing of AIDS-related news, but the underlying point of view that may have led to the conscious or unconscious choice of frames. Journalism's slow start in recording the AIDS crisis is recounted by Kinsella (1989; see also Diamond, 1990; Stein, 1988). In addition to slow initial reporting of the AIDS crisis, numerous increases and decreases in the quantity of news stories reported can be identified. Two of the most significant increases in American media reporting came with the death of Rock Hudson in 1985 (Kinsella, 1989), and with 
Johnson's announcement (Gallagher, 1991). Gallagher (1991), reporting in the alternative news magazine the Advocate states that:

Media coverage that followed the announcement was extensive and wideranging, covering topics as diverse as HIV transmission routes, the best ways to tell children about Johnson's announcement, and the reaction of firms that had hired Johnson to endorse their products. In the week after the announcement, the Los Angeles Times published more than 125 articles about Johnson, while the New York Times published more than 50. (p. 14)

Although my primary focus in this work is not the quantity of reporting related to AIDS, it is significant to contrast the virtual absence of AIDS reporting by the New York Times in the early years of the crisis, to the Times publication of over 50 stories in the week following Johnson's announcement. The first lengthy feature done on AIDS by the Times appeared on June 16, 1983, nearly two years into the crisis (Kinsella, 1989). Before that time the Times coverage of AIDS was infrequent. By the end of 1982, with 881 confirmed cases of AIDS, the Times had run only five stories on the disease. Kinsella comments that:

In 1982, the scourge of gays never made it to page A1, although the same year the Times ran four front-page articles on the Tylenol scare. The newspaper ran more than fifty articles on the three-month ordeal that left seven people dead ( $p$. 66) .... the rise and fall of media interest had little to do with the degree of crisis.... contaminated Tylenol seemed to be a threat to every American.... Legionnaire's disease struck white, middle-aged and elderly men, whom many newsmakers focus on when producing the news. on the other hand, in the beginning AIDS affected social outcasts: gays. (p. 2) 
In contrast, the alternative press began reporting news about AIDS early in the crisis. The New York Native led the way with early reports of the new disease in May of 1981, and again in July of 1981 by publishing "Cancer in the Gay Community" which offered the most comprehensive look at the disease in non-medical media to-date, and served as the centerpiece of New York's gay education campaign (Kinsella, 1989).

By 1991, reporting of AIDS-related news by the mainstream press was no longer delayed. In fact, the New York Times published eight stories related to Johnson and AIDS on November 8, 1991, the day after Johnson made his announcement. The Times coverage included a front-page story with a photograph of Johnson.

In my study of the framing of Johnson's story, I examined articles from the New York Times written between November 8, 1991 and December 31, 1991. This time period reflects the increase, and subsequent decrease in reporting surrounding Johnson's announcement. One of the most prominent frames in my initial reading of the articles was what was left out of the reporting. In discussing the framing of news, Jamieson (1990) raises the question of what of importance was not reported, and why? only two of the articles in the Times acknowledge that over 125,000 Americans had already died from AIDS (Eckholm, 1991; Specter, 1991). Eckholm states that "the virus is no longer 
spreading explosively among gay men..." and that "so far, 200,000 people have developed outright AIDS.... and more than 125,000 of them have died" (sec. 4 pp. 1, 3). Eckholm's article appeared on the first page of section four, 10 days after Johnson made his announcement. Specter's article appeared in the sports section of the Times on November 8 , 1991 and includes acknowledgment of the "126,159 deaths since $1981^{\prime \prime}$ (p. 15).

In Portland, Oregon the oregonian also published stories relating to Johnson's announcement. The stories published in the oregonian include two references to the people who have already contracted HIV or who have died from AIDS. The first piece appeared on the sports section's first page and was written by Randy Shilts, an openly gay reporter from the San Francisco Chronicle. Shilts (1991) states that:

As of the end of september, 195,718 Americans had been reported to have the disease, and the nation's AIDS caseload is expected to surpass 200,000 cases within days. Of these, more than 126,000 have died, more than twice the number of Americans who were killed in the Vietnam war. (p. BI)

The second Oregonian piece appeared in the sports Section on November 9, 1991. Although the author does not mention the number of people who have HIV or who have died of AIDS, he discusses the scope of the disease. Frei (1991) states that:

AIDS has killed other entertainers, such as Michael Bennett, Larry Kert, Rock Hudson, Liberace 
and... AIDS has killed homosexuals, heterosexuals, and intravenous drug users. AIDS has killed victims of tainted blood supplies and of at least one careless dentist. ( $p$. B2)

Trivialization, as I define it for this study, is making light of or minimizing what has occurred to-date in the AIDS crisis. Although four separate articles (two in the New York Times and two in the oregonian) briefly discuss the scope of the AIDS crisis, I claim that not mentioning over 125,000 previous deaths in the majority of reporting of Johnson's announcement in the New York Times and in the Oregonian is an example of trivialization of what has taken place in the AIDS crisis. I do not dispute that Johnson is the central participant in an important event; however, the framing used in most of the reporting leaves out or trivializes the deaths of thousands of people.

As a critic I have the responsibility to interpret the data which are available to me, in this case the text of the articles I reviewed. Upon reviewing the Times and oregonian articles about Johnson's announcement, I was first struck by the near absence of any acknowledgement of the thousands of deaths that have occurred. Additionally, my review of the articles left me with the overwhelming feeling that the writers were trying to say that Johnson was the first important person to contract HIV. I cannot assume that readers already know how serious the AIDS crisis is. Likewise, I cannot assume that the writers know the seriousness of the crisis. Again, I feel that the omission 
of information trivializes the deaths of thousands of people. As I have previously stated, my goal is not to provide the definitive interpretation of the texts I examined but to draw attention to the act of interpretation itself.

While the New York Times and the oregonian published their stories on Johnson's announcement, the alternative presses were reporting the news or, in some instances, reacting to the mainstream reports. For instance, Christopher street, a bi-weekly, alternative news and literary magazine, publishes a column titled "Mr. Bockman Writes." In the January 6, 1992 issue of Christopher Street, Bockman (1992) voices his concern that the mainstream press did not recognize what has happened to-date in the AIDS crisis. Bockman's comments appeared in a published letter to the editor of the New York Times. Bockman states that:

For many of us who have worked in the movement for a decade, along with the gratifying expectation of greater national awareness through Johnson's welcome promise of AIDS activism comes a nagging question: Why did 120,000 people have to die before it was recognized that the AIDS virus is an all-American problem? (p. 16)

In the December 31, 1991 issue of the Advocate, a national, bi-weekly alternative newsmagazine, concerns about the trivialization of what has happened in the AIDS crisis were addressed by Rothman (1991). Rothman states that, "It's sad that someone like Johnson had to come down with 
this disease in order to give the other ten million people [worldwide] living with HIV the attention and support they deserved all along" (p. 13). The December 17, 1991 issue of the Advocate reported that the "buzzword" at a National Gay and Lesbian Task Force conference was "'Magic,' inciting both hope for greater national focus on AIDS and anger at the media hype over a celebrity's health status while millions with HIV are ignored" ("Creative Sorts" p. 10) . Taking a slightly different stance, the editor-in-chief of the Advocate addressed the history gay people have with AIDS. Rouilard states that:

For the past decade, gays, lesbians, and bisexuals have fought tooth and nail to bring AZT, ddI, and now the very hopeful 566 to people with HIV disease. Magic's life will be prolonged by our efforts. Nearly all the AIDS service organizations, all the expertise that has been developed around this disease, were initiated at the instigation of gay people. AIDS Project Los Angeles, one of the largest service providers in the world, was started in a gay bar.... Can he [Johnson] ignore the history of a movement for which he claims to be a spokesman? (1991, p. 8)

In another piece from the "Media" section of the Advocate, Gallagher (1991) comments on the trivialization of the first decade of AIDS by stating that:

Activists praised Johnson, a point guard for the Los Angeles Lakers, for making the disclosure but said they were frustrated with reporters who scramble to produce the voluminous coverage after years of paying little attention to AIDS issues in general and AIDS among racial and ethnic minorities in particular..."I think the American media revealed how totally out of proportion they view these things by treating Johnson's announcement as if it were the first major event in ten years of the HIV epidemic" said Gregory 
King, a spokesman for the Human Rights Campaign

Fund, a gay lobby. (p. 14)

In addition to framing that trivializes what has happened in the AIDS crisis, instances of marginalization can also be seen. Marginalization, as I define it, is showing those affected by AIDS (people with AIDS, friends, family, and loved ones) as being on the outside or fringe of the mainstream or majority. In reporting related to Johnson's announcement, examples of marginalization can be seen in the framing selected by the mainstream press. For instance, Vecsey (1991) writing in the sports section of the New York Times begins by taking a sympathetic perspective towards people affected by AIDS in the "first decade of the plague." He states that:

Close friends changed their lives because of the plague. They switched careers, moved across the country, became celibate, started watching sitcoms at home rather than going out, nursed friends, nursed strangers. For them, life in the $80^{\prime} \mathrm{s}$ became considerably less gay. (p. 30)

Vecsey does not necessarily trivialize what has happened in the past decade; however, I claim that, as he continues, his comments marginalize those affected by AIDS:

More recently, we have learned that AIDS strikes women, strikes blood-transfusion patients, strikes drug users who share dirty needles, strikes heterosexuals. But always the plague carried the image of the first generation... . Now AIDS has a celebrated male, adult victim who will capture the attention and sympathy of a huge segment of the world... . Now he is the most prominent person to ever go public about AIDS. He is telling us that if Magic Johnson, a heterosexual man, can get AIDS, then so can a lot of other people. (p. 30) 
I maintain that in 1991, to frame learning that AIDS affects women, blood-transfusion patients, IV drug users, and heterosexuals as a recent event, is not only outdated information, but further marginalizes those affected by AIDS in the early history of the crisis: gay men. The choice of framing AIDS as a "plague" and linking the plague language to the "first generation" [read gay] as well as claiming Johnson as AIDS celebrated, prominent, heterosexual, adult male victim, further marginalizes those most affected by AIDS: again, gays. Vecsey's comments lead me to ask, will Johnson, clearly presented in the frame as a heterosexual male, also speak for homosexuals? And if Johnson, again framed as a heterosexual, can get AIDS, who are the "other people" Vescey claims can get the disease?

Writing in the oregonian, Frei (1991), as I have stated earlier, acknowledges those who have been affected by AIDS in the past. However, he goes on to marginalize those affected by AIDS today:

Magic says he's going to be around a long time, let's hope he's correct. This is not going to be: Magic's got AIDS, so let's get Congress and the administration to fund more research; so let's distribute condoms; so let's do what we should have been doing long before now. Yet this HIV case is going to shake us like no other. I am not sure that's right. I am absolutely certain that's true. I am also sure you know what I mean. (p. B2)

Frei's (1991) comments again lead me to question, why is Johnson's announcement not going to lead to added funding for research, increased distribution of condoms, and doing 
what should have been done long before now? And what is Frei attempting to frame when he says that Johnson's HIV case will shake us like no other, and stating that he is sure you know what he means? Can he mean the tens of thousands of gay men who have died already? However, Frei's commentary illustrates the ambiguous nature of interpretation. It is possible to interpret what Frei says as disapproval of a society which has been slow to react to the AIDS crisis.

The issue of the mainstream press marginalizing those who are most affected by AIDS did not miss the alternative press. Commenting in the Advocate about the tangled bureaucracy people with AIDS face and the public image problems Johnson may face if he develops AIDS, Rouilard (1991) asks:

Do we have another Kimberly Bergalis on our hands? will Magic play right into the hands of the second decade of the Republican party's successful AIDS strategy: trivialization through compassionate lip service to "innocent" victims like Kimberly Bergalis, Ryan White, and Magic Johnson? It must be very tempting to get all that sympathy and take none of the shit that nearly 1 million HIVpositive Americans face every day..... Will the spokesperson for people with HIV visit the Ryan White memorial but not an AIDS hospice in a gay neighborhood? (p. 8)

In writing about the mainstream media approach to Johnson's disclosure, Gallagher (1991) states that:

Activists said that several reports and columns approached insensitivity.... Los Angeles Times writer Jim Murray, wrote that "HIV may have picked the wrong guy this time"....comments like Murray's reinforce the view that AIDS is only real when it 
touches someone who is not gay or an intravenous drug user or related to them.... [this is similar to] reporting about AIDS among gay men in the early'80s, when writers frequently called heterosexuals the "general population." At that time, AIDS activists objected to the usage, saying that it marginalized HIV-positive people.... it's a given that AIDS affects gay men, so the hidden "subtopic" of the barrage of stories was that Johnson is somebody who counts, somebody who's not gay. (p. 16)

ROCK HUDSON

To gain a better understanding of the media framing of Magic Johnson's announcement, it is helpful to look back to a similar announcement by actor Rock Hudson in 1985. The 1991 mainstream and alternative reporting of Johnson's HIV status contained references and comparisons to Hudson's announcement that he had AIDS. The New York Times quoted Dr. Jerome Groopman, an AIDS researcher, as saying Johnson "displayed tremendous courage....this is the flip side of Rock Hudson....he affirmed his situation, he stated that he would fight it and work to help others as opposed to putting forth a false diagnosis as a smokescreen" (Kolata, 1991, p. B15) . Also, specter (1991) reported in the Times that:

Just as the news that actor Rock Hudson had AIDS shocked millions out of complacency in 1985, the disclosure that Johnson is infected with... AIDS, will unquestionably have a similar effect on people. But where Hudson was a beloved entertainment figure whose illness came as a shock because he crushed the prevailing secrecy surrounding the disease, Johnson's face is on products and posters in children's rooms throughout the country. (p. B15) 
Additionally, Eckholm (1991) reporting on Johnson's announcement in the New York Times states that:

Compared with the frenzy triggered by Rock Hudson's stunning disclosure of AIDS back in 1985, Johnson's announcement suggested just how far the country has come. Hudson hid his disease in shame almost to the end, speaking out only after reporters learned of his pitiful pilgrimage to Paris for an untested cure. (sec. 4 p. 1)

Similarly, the oregonian picked up a story from the san Francisco Chronicle in which Shilts (1991) comparing Johnson and Hudson states that:

Since AIDS was first detected, Magic Johnson is the biggest celebrity to acknowledge publicly that he is infected by HIV. The only person of comparable fame was the late actor Rock Hudson, who revealed that he had AIDS in July 1985. That announcement galvanized public attention to a disease that had been largely ignored before then. The publicity surrounding Hudson's battle with AIDS resulted in intense media attention and the infusion of hundreds of millions of dollars in government financing into AIDS research and prevention. (p. B1)

Finally, reporting in the Advocate on the mainstream media coverage of Johnson's disclosure, Gallagher (1991) states that Johnson's announcement "triggered a week of media attention to AIDS that was rivaled only by the fire storm that surrounded actor Rock Hudson's 1985 disclosure the he had AIDS" (p. 14).

In looking back to the media reports of Hudson's announcement, the similarities and differences in reporting between 1985 and 1991 become more clear. The New York Times first reported news about Hudson on July 24, 1985. The article appeared on page sixteen of the Entertainment 
section, and simply reported that Hudson was "seriously ill with inoperable liver cancer" ("Rock Hudson," 1985, Sec. 3 p. 16). The article also noted that there had been reports that Hudson was suffering from AIDS. Two days later, July 26, on page 3 of the Entertainment section the Times reported that Hudson had AIDS and that he had been diagnosed twelve months earlier. The article continued by asking:

How the actor acquired the disease, which most frequently strikes homosexuals, intravenous drug users and recipients of blood transfusions, Miss collart [spokesperson for Hudson] said, "He doesn't have any idea now how he contracted AIDS. Nobody around him has AIDS." ("Hudson Has AIDS," 1985, p. C3)

Subsequent reporting in the New York Times included a report that AIDS hotlines were receiving more calls since Hudson's announcement. The article quoted Barry Davidson, director of community information at the Gay Men's Health Crisis, as saying, "I guess some people feel that if Rock Hudson has AIDS, they can start asking questions that they were insecure about asking" ("New York Day," 1985, p. 26). On July 30, 1985 Altman stated in the Times that:

As a movie star, Mr. Hudson is the best known American to acknowledge publicly that he has AIDS. Many of its victims and others have expressed hope that Mr. Hudson's personal tragedy will bring about a greater public awareness of the seriousness of the AIDS epidemic and spur the government to play a greater role in researching and treating this invariably fatal disease that was first recognized in 1981. (sec. 3 p. 1)

In a New York Times piece about AIDS and homosexuality in the "Old and New Hollywood," Harmetz (1985) states that, 
"Although Mr. Hudson has never publicly said he is homosexual, numerous articles gave that impression. Dale Olson, Mr. Hudson's publicist, said Mr. Hudson would not be making any statement in response to the articles." Later in the same article, Harmetz quotes the chairman of Universal Pictures responding to concerns about a backlash against Hollywood, "When you have the President of the United states making a sympathy call to Rock Hudson, you don't have to fear a backlash" (p. C15). Finally, on october 3, 1985 the Times reported on page 23 of section "D" that Rock Hudson had died. The report was essentially a review of Hudson's career (Berger, 1985).

At the same time in Portland, oregon the oregonian was also reporting news related to Hudson's announcement. An October 3, 1985 front page article reported that:

Rock Hudson, the cinema idol whose gallant admission of a yearlong battle against AIDS won sympathy and attention for victims of the disease, died Wednesday in his home.....As of Monday [September 30 ], there were 13,611 reported cases of AIDS in the United States, and 6,944 of the victims had died.....Hudson's homosexuality had been rumored for years. Even after his iliness became known and several magazines carried sympathetic articles describing Hudson as a homosexual, the actor kept silent. (Benke, 1985, p. 1)

Subsequent oregonian articles included a review of his career (Thackaray, 1985), a short piece on a government bill to close gay bathhouses ("House OKs," 1985), and celebrities comments on Hudson's death (Manning, 1985). 
Meanwhile, the alternative press was also reporting news about Hudson. On August 20, 1985 the Advocate published a brief article announcing that Hudson had AIDS ("Rock Hudson," 1985). On September 3, 1985 the Advocate published a "Mediawatch" article in which Daniels writes:

"Now the militant homosexuals have a celebrity disease of their own," wrote Wesley Pruden in the Washington Times.... Time magazine reported, last week as Hudson lay gravely ill with AIDS in a Paris hospital, it became clear that throughout those years the all-American boy had another life, kept secret from his public: he was almost certainly homosexual... . Howard Rosenberg [Los Angeles Times] wrote..."It was tacky. But Hudson is a celebrity and a Hollywood institution, so fair game. The coverage has even focused desperately needed attention on the growing problem of AIDS." (p. 22)

As I have previously stated, access to the alternative presses' reporting of Hudson's announcement was limited. But author Randy Shilts provides an alternative point of view in his account of the AIDS epidemic, And the Band played on (1987). Writing about Hudson, Shilts describes news organizations that suddenly became hungry for stories about AIDS, or at least stories about the actor. Shilts states that:

The major problem most news organizations confronted with the Hudson story was in explaining how the actor got AIDS. of course, virtually everyone in the Hollywood film community had known for decades that Hudson was gay. Homosexuality, however, was an issue about which the media still felt much more comfortable lying than telling the truth. Consequently, the news stories about Hudson's health hedged the issue, alluding only to the CDC's standard list of risk groups.... [many gay groups preferred it this way stating that] "AIDS is not a gay disease" and that "AIDS is not 
a gay white male disease" as though Hudson were something other than a gay white male. (p. 577)

Shilts continues explaining how AIDS had reached the front page of most newspapers because of Hudson. The man who for decades had "personified wholesome American masculinity" (p. 578), was seen as both being gay and dying from AIDS. Shilts concludes that many saw Hudson's announcement as the single most important event in the history of the crisis.

In February of 1987 , Christopher street published a summary of an interview with Rock Hudson. At the end of the piece the author comments on Hudson's disclosure and the media's reaction. Hadleigh (1987) states that:

If Rock Hudson had died of cancer or a heart attack, his death would likely have received small press attention. But once it became known that he had AIDS, everyone took a second, long look at him. Despite his own reticence and that of his mostly gay associates, Rock's homosexuality finally became a worldwide secret.... The media overkill betrayed homophobia at all levels, from the respected newsweeklies down to the gutter press. But it also made the public more aware of AIDS, showed that it could afflict the rich, famous, and admired, and it indirectly helped boost funding for AIDS research and care for AIDS victims. (p.21)

In comparing Magic Johnson's 1991 announcement with Rock Hudson's announcement in 1985, several similarities emerge. First, both Hudson and Johnson were celebrities whose names were known nationally and internationally. The disclosures by Hudson and Johnson were heralded as important events in the AIDS crisis, and, finally, both announcements were expected to bring much needed attention to the disease. 
But in examining the reporting surrounding the two events differences also emerge. Johnson made his announcement shortly after learning his HIV status, while Hudson waited until he was dying from AIDS. In fact, Hudson appeared to be hiding the truth from the public throughout his ordeal with AIDS. Johnson, on the other hand, seemed open about the disease and volunteered to help fight AIDS.

Additionally, the sexuality of both Hudson and Johnson was discussed by most of the mainstream and alternative presses at some point in their reporting of the two announcements. Johnson quickly denied any homosexual experiences (Stevenson, 1991), and Hudson was widely reported to be homosexual even though he never confirmed that fact (Shilts, 1987; Harmetz, 1985; and Benke, 1985). One of the more relevant comparisons for this study is the increase in reporting of AIDS-related news that took place with the announcements of Hudson and then Johnson. Kinsella (1989) in writing about AIDS, the American media, and Rock Hudson states that:

After months of scant reporting on AIDS, media coverage across the United States boomed, especially in broadcast. For instance, in 1985 ABC did four AIDS stories before the July 25 Hudson revelation, and twenty-eight after. CBS and NBC had similar leaps in coverage. Nationwide, media coverage tripled. In some cases, publications, including major dailies in the heartland, were writing about the disease for the first time, not merely picking up the wire service copy. AIDS reporting in print media increased by 270 percent between Hudson's diagnosis and the end on 1985. By going public with his ailment, Rock Hudson obviously had not 
set off spontaneous research, nor had he provoked the rash of other issues that were finally being covered... The simple fact is, newsmakers from the executive producer at the major networks to the assignment editor on the metropolitan daily in Des Moines, were for the first time touched in a direct, personal way by the epidemic. (p. 144)

Kinsella (1989) suggests that there was a shift in the media's attitude after Hudson's announcement. He attributes this change to his "personal threat" rule which states that, "the closer the threat of the disease seemed to move towards those setting the agenda, the bigger the story became" ( $p$. 252). The rule applies to Hudson's 1985 disclosure which Kinsella identifies as one of the three peaks of AIDS reporting between the start of the crisis and the late $1980^{\prime} \mathrm{s}$. Kinsella attributes the low points in media coverage to the fact that AIDS was not perceived to be a threat to the "average white, heterosexual, middle-class person" (p. 252). The "personal threat" rule can also be applied to the relative absence in mainstream reporting of AIDS news before, and the rise in reporting after Magic Johnson's announcement. Mainstream media reports about Johnson frequently stated that if Johnson, a famous, heterosexual athlete could get AIDS, anyone could; hence, a personal threat to the mainstream.

The fact that reporting of AIDS news has quantitatively high and low points is important to my thesis. Something has to attract the attention of the media and hold that attention. Kinsella's (1989) personal threat rule may 
partially explain attention or lack of attention by the media. But Klass (1991) offers a different view of the media. In reporting from the Seventh International Conference on AIDS, held in Florence, Klass states that:

There are some 800 representatives of the news media and more than 8,000 delegates at the convention -- a ratio of about 1 to 10. At times it seems that the speakers are speaking to the news media, the protestors protesting for the reporters' benefit, the interchange among delegates little more than an excuse to invite in the press. (p. 26)

Klass's 1991 representation of the media and their approach to AIDS was published in the New York Times Magazine section approximately ten years into the AIDS crisis. As Kinsella (1989) and others document, this is a significant change from the early days when the Times did not report AIDS news, to the Florence conference where the media appeared to be almost too interested, to the Times devoting nearly four pages of its Sunday magazine section for AIDS conference coverage.

It is clear that reporting AIDS news by the mainstream press increased after both Hudson's and Johnson's announcement. The framing of both announcements was similar in that articles about Hudson and Johnson essentially excluded discussion of those who had already died from AIDS. Additionally, Hudson's disclosure tends to marginalize those most affected by AIDS in that Hudson chose to deny that he was homosexual. But the media did not deny what many people knew and focused much of their attention on Hudson's 
sexuality. In comparison, Johnson's sexuality was seldom questioned. It is also clear, particularly in the New York Times, that the approach to AIDS news coverage changed between the announcements by Hudson and Johnson. None of the Times articles on Hudson appeared anywhere near the front page. Most were located in the entertainment section, including notice of Hudson's death. But reporting of Johnson's announcement six years later warranted a front page lead story, with a photograph, plus seven follow-up stories the same day, in the Times. Kinsella (1989) has documented the changes in editorial policy towards AIDS reporting at the New York Times which may account, in part, for the placement differences in articles on Hudson and Johnson.

\section{SUMMARY OF FINDINGS JOHNSON/HUDSON}

At this point it is appropriate to step back and examine what I have laid out so far, specifically the announcement by two celebrities of their AIDS status, and the mainstream and alternative media reporting of those announcements. At this stage of my study several patterns seem to be emerging, for instance: there was an increase in reporting when Johnson and Hudson made their announcements; instances of trivialization as a frame can be found in mainstream reporting of Hudson's and Johnson's announcements; instances of marginalization as a frame can 
be found in mainstream reporting of Hudson's and Johnson's announcements; and it is apparent in the articles I reviewed that the sexuality of people with AIDS or HIV is related to how news about AIDS is framed.

At this stage of my study, I have found little evidence of disparagement by numbers as a frame for reporting news about AIDS. I define disparagement by numbers as underreporting, an absence of reporting, or incorrect reporting of AIDS-related statistics. In relation to the disclosures by Hudson and Johnson, the mainstream press reported very few AIDS-related statistics. The few figures that were given were generally attributed to the Centers for Disease Control, and were limited to stating how many people are thought to have HIV and AIDS. In several instances statistics were reported in terms of race and gender. However, in accordance with my definition of disparagement by numbers, there was an absence of reporting of the numbers of gay people who have HIV or AIDS in the mainstream media reports about Johnson and Hudson.

Finally, it is pertinent to note the differences between the individuals I discuss in this portion of the study. Johnson is one of the best known sports figures of our time. While Hudson, at the time of his announcement, was essentially a retired actor with AIDS. My intent is not to compare the individuals but to contrast the reporting about the individuals. At the time Johnson made his 
announcement numerous reporters made references and comparisons to Hudson's announcement (see Kolata, 1991; Specter, 1991; Eckholm, 1991; Shilts, 1991; Gallagher, 1991). Based on these and other references it seemed of value to contextualize what was being reported about Johnson by looking back at a similar event.

OTHER AIDS-RELATED NEWS

At the same time news related to Magic Johnson's disclosure was reported, other AIDS-related stories were in print. Like the news about Johnson, these stories provide an opportunity to examine the framing of news related to the AIDS crisis by both the mainstream and alternative presses. To add consistency to the study, I examined the framing of news during the same time period as news about Johnson was in print. The additional reporting I used concerns individuals and their struggles with AIDS.

\section{Kimberly Bergalis}

At the same time news about Johnson's announcement appeared in print, news about a Florida woman who was dying from AIDS-related complications was being reported. Kimberly Bergalis might have quietly died with no media recognition but the circumstances surrounding her AIDS case made her a media celebrity. Bergalis traced her infection to her dentist who continued practicing several years after learning he was HIV positive. The New York Times reported 
that:

Bergalis was the "poignant symbol of scientific mystery and a continuing debate over the risk of infection in health care settings and what to do about it.... But others said that Ms. Bergalis stirred unwarranted panic and that her case diverted attention from the far more common spread of the disease by unprotected sex and the sharing of tainted needles by drug abusers." (Lambert, 1991, p. D9)

Most of the reporting of the Bergalis story centered on one of two issues: mandatory HIV testing for health care professionals, and the media presentation of Bergalis as an innocent victim. Goodman (1991), reporting in the New York Times addressed the media image of Bergalis as she appeared before a Congressional hearing on the mandatory testing issue:

\footnotetext{
Ms. Bergalis is presented as an innocent, in contrast to others infected with AIDS like homosexuals and drug users. The point is pressed home that she caught it from one of them. (Rep. William Dannemeyer, a California Republican and chief sponsor of the Kimberly Bergalis bill, maintains that homosexuality itself is an illness.) In the heavily covered Congressional hearings, George Bergalis, Kimberly's father, took the occasion to announce he was not a civil libertarian or a homosexual. What feeling was that meant to provoke in middle America? (p. 31)

Unlike much of the reporting of Johnson's HIV status, the previous article acknowledges that others have contracted HIV and are dying from AIDS. Again, reporting in the New York Times Shilts (1991) discusses Bergalis'
} innocence:

What is also troubling about the anger of the Bergalises is that they do not seem to acknowledge 
the suffering of others. When their daughter spoke before Congress in October to lobby for legislation that would require testing of health care workers for the virus that causes AIDS, she mentioned how unfair it was that she had to suffer from AIDS even though she "didn't do anything wrong." With those words she seemed to be separating those who don't deserve AIDS from those who do. These are troubling words.... Gay men express their love differently from the majority, it's true, but those who contracted AIDS didn't do anything "wrong." ...AIDS has spread without a concerted Government response because so many Americans believe that only people who have done something "wrong" get the disease. Ms. Bergalis and many others might be alive now if those fighting AIDS did not also have to fight this prejudice. It's appalling that AIDS is considered serious only when it strikes a heterosexual young woman or a star basketball player. (p. 31)

The Bergalis story was reaching its conclusion as the news about Johnson was being reported. Bergalis died on December 9, 1991. The articles I examined from the New York Times discussed the mandatory testing issue, the dentist who may have given Bergalis HIV, the innocence of Bergalis, or generally a combination of all three of these issues. Some of the reporting, most notably the pieces by Shilts (1991) and Goodman (1991), frame Bergalis as someone who has gained access to the media and who is, at least in part, supporting the mainstream image of AIDS as someone else's disease. But both shilts and Goodman are writing in the Times and they are reporting about an individual whose statements marginalize those who are affected by AIDS. Essentially, both writers are critical of either the media for framing Bergalis as innocent or of the government for their slow response to the AIDS crisis. 
On December 9, 1991 the oregonian reported that Bergalis had died. In the article Bergalis is again quoted as saying that she "did not do anything wrong" (p. 1). The article also discusses the september trip Bergalis made to Washington to lobby Congress for passage of a bill that would make AIDs testing mandatory for some health care workers :

As moving as her 15-second testimony was, however, the so-called Bergalis bill died in committee and Bergalis herself touched off a controversy when many AIDS activists saw her as a focal point of a conservative backlash directed at gays. (p. 1)

The oregonian also mentioned the fact that since the AIDS crisis began the disease had claimed 113,000 lives in the United States.

Meanwhile the alternative press was also reporting news about Bergalis. Gallagher (1991), reporting in the Advocate, claimed that Bergalis had a serious impact on the public perception of the AIDS crisis and that the media needed a heterosexual angle to continue reporting AIDS news. Gallagher states that:

The human-interest angle overwhelmed the scientific aspect of the story. Instead of a medical mystery about how Acer [Bergalis' dentist] may have transmitted the virus, the story became Bergalis. Articles about the medical or policy issues surrounding the Acer case, such as appeared in the New York Times and Time magazine, were illustrated with her photo. (p. 34)

Gallagher continues by citing Kinsella and his personal threat theory as it relates to the reporting of AIDS-related news by the mainstream press: 
"The reason why it's covered is that it looks once again like it could be affecting us, the people who determine news in a paper -- people who are white, middle-class, and generally males," says Kinsella. "They say in the newsroom... if it could happen in a dentist's chair, it could affect me." (p.37)

Reporting in Christopher street Bockman (1992) in his

"Mr. Bockman Writes" column publishes a letter he wrote to the Editor of Time magazine:

Your coverage of Kimberly Bergalis's alleged contraction of AIDS from her dentist showed very little understanding of the hysteria surrounding the issue. The photo caption used the phrase "innocent victim," the rallying cry of those who seek to stigmatize people with AIDS.... A little more objectivity would be of great comfort to the thousands of other people with AIDS, none of whom are to be blamed for contracting the illness. ( $p$. 16)

Finally, in a discussion of the language surrounding HIV and AIDS, Botkin (1991) addresses the use of the term "innocent victim," stating that it is a euphemism for "AIDS victims we care about." Botkin refers to an example of how the media expresses concern about children with AIDS:

Technically, any infant infected in the womb is, clearly, "innocent." But, according to a paper published at the recent International Conference on AIDS, the media focuses almost entirely on children born to mothers accidentally infected by contaminated blood, and ignores the offspring of moms who got HIV from sex or drugs...."Innocent victim" really applies to how much society values the given "victim," and not to how you got the virus. (p. 23)

Unlike Johnson, Bergalis was not a celebrity who contracted HIV, she was an individual who contracted HIV and was essentially turned into a celebrity by the media. The 
media framed Bergalis as an innocent victim. I claim that framing an individual as innocent, or as a victim is an example of trivializing what has occurred to-date in the AIDS crisis, and further marginalizes those most affected by AIDS. It is trivializing for the media to not acknowledge thousands of deaths which have already occurred. Additionally, the framing of an individual as innocent further marginalizes those affected by the AIDS crisis by again placing them on the outside or fringe of the mainstream. Like the reporting of Johnson's disclosure the reporting and framing of Bergalis' story included examples of reporting that did not trivialize or marginalize what has happened in the crisis or those affected by the crisis. These examples include the reporting by Shilts (1991), and Goodman (1991).

\section{MARK WOODLEY}

In 1989, Mark Woodley was hired by Macy's department store to be one of 26 Santas for that year. What Macy's didn't know when they hired Woodley was that his partner had just died of an AIDS-related condition. But Woodley was so successful in the Santa position that Macy's asked him to return in the Fall of 1990 . On his employment application for the 1990 season woodley disclosed that he was HIV positive, that he was taking the AIDS drug AZT, and that he takes Prozac, a drug for depression, to help him cope with 
the loss of friends to AIDS and his own poor prognosis. When Woodley arrived for his first shift he was denied entrance to Macy's and several days later he was told that he would not be rehired as santa, but was offered a job supervising the Santas.

Woodley's story was reported in the New York Times as his lawsuit against Macy's dragged on and as he became a volunteer Santa appearing at parties for children with AIDS. The Santa story was also carried by two alternative presses: the New York Native, and the San Francisco Bay Area Reporter. Unlike some of the reporting I have examined in this study the woodley story is reported in a vary similar manner in both the mainstream and alternative presses. However, there are a few differences. For instance, the New York Native states that Woodley's "lover" had died from AIDS and quotes Woodley as saying he was "the most important person in my life" (Hammond, 1991, p. 8). The New York Times referred to Woodley's partner as "a friend who died of the disease, (Martin, 1991, p. 22) and as "the deaths of several gay friends" (Margolick, 1991 p. B1) .

Several other minor differences were reported in relation to Woodley's story. The New York Times reported that the AIDS advocacy group, ACT UP, staged a protest at Macy's in support of Woodley $(1991, \mathrm{p} .22)$, and the New York Native reported more background or human interest information about Woodley. 
The Macy's Santa story, other than the few differences I have pointed out, was reported or framed in essentially the same manner by both the mainstream and alternative presses. Woodley was generally framed as a gay man struggling with the loss of a partner and friends, his own declining health, and the desire to work in a job that he described as the "perfect tonic" (Hammond, 1991, p. 8). Both the mainstream and alternative presses framed Macy's as a company faced with making public decisions about a deadly disease. In one instance, the New York Times quoted Woodley as saying, "I thought they'd be enlightened and informed about HIV, and that I wouldn't have to worry about misinformation and fear" (Margolick, 1991, p. B1). In another instance the Bay Area Reporter places Macy's in frames that not only reveal a fear of AIDS but also a possible fear of homosexuals. A Macy's vice president stated that concern about a gay man in recovery whose health is precarious is "misplaced and based on misinformation." And an October deposition by the Macy's personnel administrator who refused to rehire Woodley reveals she made the decision because an "HIV-positive santa might give pneumonia, meningitis or tuberculosis to children at Macy's" (Cokin, 1991, p. 20).

In relation to Woodley's story, and unlike the other stories I have used in this study, the alternative press is not critical of the mainstream reporting of the santa story. 
In fact, both the mainstream and alternative presses appear to be critical of Macy's. In this particular example of reporting of AIDS-related news, I found no instances of marginalization, trivialization, or disparagement by numbers.

\section{CHAPTER SUMMARY}

In summary, the articles I used in this study are a sample of AIDS-related reporting by the mainstream and alternative presses. From this study I am able to claim that some of the mainstream reporting involves the use of frames which trivialize and marginalize according to my definitions. I do not claim that all AIDS-related reporting uses frames which trivialize or marginalize. Again, based on this study, I am able to claim that some of the alternative press reporting is commentary on the reporting done by the mainstream. 


\section{CHAPTER V}

\section{INTERPRETATION}

The examination of news framing is intended to be a vehicle to move me from a rhetorical artifact, in this case the text of the articles I reviewed, to the interpretation of the artifact. Therefore, it is pertinent to address Gitlin's (1980) questions which are aimed at an analytic approach to the media: What is the frame? Why is this frame, and not another, used? And, what difference do the frames make for the larger world?

To some extent I have already answered the first question in identifying the frames used by the mainstream press that trivialize and marginalize. It is the second question: Why is this frame, and not another used? That leads me to the center of this discussion. On the surface it seems adequate to state that news related to AIDS, in this case news about celebrities, is framed in ways which support the dominant ideology of our culture, or at least the ideology of the presses involved. It has been well documented that the New York Times is the voice of record or the agenda setter for American news reporting. As the agenda setter for much of American news reporting, the Times daily has the opportunity to reinforce mainstream ideology 
on its own pages and, by setting the agenda, on the pages of papers across the nation. But this only begins to answer the question: Why was this frame used? A more complete analysis is necessary to discover possible reasons for the choice of particular news frames used by the mainstream press.

THE LANGUAGE OF AIDS

Part of the answer lies in the way AIDS, the disease, is discussed or framed in our society. Metaphors for disease and AIDS, as Sontag (1989) observes, are inevitably oppressive. Sontag states that: "Disease is seen as an invasion of alien organisms, to which the body responds by its own military operations, such as the mobilizing of immunological 'defenses,' and medicine is 'aggressive,' as in the language of most chemotherapies" (p. 9). Sontag also states that: "military metaphors contribute to the stigmatizing of certain illnesses and, by extension, of those who are ill" (p. 11). Finally, sontag discusses the stigma associated with AIDS:

With AIDS, the shame is linked to an imputation of guilt; and the scandal is not at all obscure..... It is not a mysterious affliction that seems to strike at random. Indeed, to get AIDS is precisely to be revealed, in the majority of cases so far, as a member of a certain "risk group," a community of pariahs. The illness flushes out an identity that might have remained hidden from neighbors, jobmates, family, friends. It also confirms an identity and, among the risk group in the United states most severely affected in the beginning, homosexual men, has been a creator of 
community as well as an experience that isolates the ill and exposes them to harassment and persecution. (p. 24)

Smith (1991), like Sontag (1989) discusses the metaphors associated with AIDS. But Smith is not in complete agreement with Sontag's assertion that we should abandon illness metaphors. Smith claims that some metaphors empower people while others can cripple people with "anxiety, guilt, and alienation" (p. 14). Smith, in opposition to sontag, believes that the metaphor, "War on AIDS," is useful to keep as it both hides and reveals aspects of the disease. Smith states that:

AIDS has thus far threatened, for the most part, only stigmatized minorities generally despised by the larger, so-called "general population"; whereas the war metaphor can stir up our worst militaristic adrenalin.... AIDS requires compassion....the war metaphor can mislead us, hiding from view those elements of the AIDS experience which do not fit into the categories of war.....At the same time, however, the war metaphor reveals certain elements of the experience of AIDS. As in war, AIDS claims the lives of loved ones, especially the young. As in war, the heroism of many PWAs and their caregivers becomes so apparent. (p. 14)

Additionally, Taylor (1990) feels that it is naive to denounce illness metaphors as Sontag (1989) suggests, and that we should instead attempt to understand the cultural logic that underlies AIDS metaphors. Taylor states that:

Many Americans fear and detest AIDs more for its perceived association with a "debauched" lifestyle, most notably, homosexuality and intravenous drug use, than for any direct health threat to themselves. The moral judgments leveled against gay men and IV drug users by certain segments of the American population have become part of AIDS 
as "illness," part of AIDS as a "social construct." This construct, I maintain, has influenced the response that American health authorities have taken against AIDS as much as, if not more than, scientific thinking about the "disease" component of AIDS. (p. 55)

Treichler (1988) again in opposition to Sontag (1989) states that "no matter how much we may desire...to resist treating illness as metaphor, illness is metaphor," and that "this effort to 'make sense of' AIDS - has to be done" ( $p$. $34)$.

Finally, Berube (1988) writing in outlook, an alternative, quarterly publication discusses the impending death of his lover and their reaction to the disease. Berube states that:

Like many other disasters, this epidemic is a part of nature that devastates our lives and makes us wonder why. Yet AIDS is nothing more or less than a disease that is killing human beings. It is a natural event that exists because it exists. While HIV itself may have no inherent meaning or purpose, the ways that Brian and I responded to its presence in his body made all the difference in the world. We realized that the power to create or destroy meaning was in us, not in the virus. While the virus had the power to kill without intent, we had the power to create meaning out of our responses. (p. 11)

There is yet another perspective of how AIDS is framed in our society. In a recent study, Drushel (1991) examined the Associated Presses stories on AIDS to evaluate the effect of language in reporting. Drushel found little evidence of distortion associated with the choice of words in reporting. However, the author speculated that distortion might be found in the selection, editing, and 
presentation decisions made by the press. Drushel states that:

Sensational headlines, photographs, and other visuals can alter the news consumer's perceptions. Omission of facts, especially background information that is key to accurate framing of the story, may result in the popular view of the AIDS story as merely a collection of tragic deaths, conflicting opinions on the relevance of social taboos, and dire yet vague predictions about the survival of our race, instead of as a health issue which has broad implications for society and which demands responses which are reasonable, well

thought-out, and yet timely. (p. 60)

Drushel concludes that another possible source of distortion in AIDS reporting by the mainstream press may be found in the choices writers make about which aspect of the story to emphasize. Reporters may direct attention to tangible facts such as case studies, or they may choose to focus on areas of high conflict. Either choice, Drushel claims, may trivialize the story and relegate the real issues to a secondary role.

\section{THE GAY RIGHTS MOVEMENT}

Returning to the question, why was this frame, and not another used? The ways in which disease and AIDS itself are framed or discussed in our culture can be seen to influence how the media might frame news about AIDS. But I argue that the choice of frames used by the mainstream media goes beyond the rhetoric of AIDS, the disease. To discover why specific frames associated with AIDS may be used by the mainstream press one must look at the context of AIDS in 
relationship to gay people and the gay rights movement. Darsey (1991) examined the changes in discourse of a social movement, the gay rights movement, over more than four decades and hypothesized that particular events provided meaningful divisions in the rhetoric of the movement. For instance, the first significant period Darsey studied corresponded to the time of Joe McCarthy's prominence from 1950 to 1954, and was characterized as a period of establishing groundwork for the movement. Additional "rhetorical era's" Darsey examined include the 1969 New York City gay riot known as stonewall, identified as a period of aggressive self-identity, and the emergence of Anita Bryant in the late $1970^{\prime} \mathrm{s}$, identified as a period of work, determination, and strength for the movement.

The appearance of AIDS in 1981 marks the final event in Darsey's study. The author states that "AIDS has become the obsessive concern of gay rights activists, coloring all activity concerning the welfare of gay men and lesbians in the United States. AIDS presented the gay community with not only a public health crisis, but crises in the social, legal, and psychological spheres as well. AIDs catalyzed a shift in the rhetoric of the gay movement" (p. 55). The change in rhetoric was reflected in alternative publications like the New York Native which featured one of the first stories on AIDS and a year into the crisis, 15 of the Native's 40 news pages featured AIDS-related stories. 
Furthermore, Darsey identified appeals for justice in relation to the AIDS crisis, and states that, "there is little faith that government, left to its own devices, will look after the best interests of gay people" (p. 56). The Government role in the AIDS crisis is a major focal point for the rhetoric of this period. For example, the alternative publication Windy City Times expressed their belief "firmly and unequivocally, that if AIDS were a disease that struck primarily white, heterosexual men, these and other solutions [funding and treatment issues] would long ago have been implemented" (p. 56).

Darsey also found a renewed concern with truthfulness in the gay presses concerning the correction of "general misconceptions about gays perpetuated by the mainstream media" (p. 57). But most of the appeals for truthfulness were connected specifically to AIDS. Darsey examined an editorial from the windy city Times which asks:

...gays to be truthful with themselves and in their relationships with others about who they really are, and it rests its political agenda on the sanguine assumption that direct knowledge of gay people effectively will combat harmful myths and misconceptions: To know us is to love us. ( $p$. 57)

Darsey (1991) further asserts that an appeal to truthfulness is important in the movement and that it is the burden of gays to tell the truth whenever inaccuracies are promulgated. As long as gays are represented through the eyes of mainstream media, (the press, movies, and 
television) then the truth is at stake. All oppressed groups are in some way alien to their oppressors, and it is this difference between groups that is at the source of oppression. It is difficult to oppress ourselves, or those who are like us; it is not so difficult to oppress those who are alien. But it is not wise to lose all diversity; to become too like the oppressor, "...this is the fundamental question for any movement for social reform.... how much do we become like them in order to enjoy the fruits of what they call success, and how much do we make them acknowledge that there are alternatives that must be respected" (Darsey, 1991, p. 60).

One distinction of marginal groups is that they are bound together, in part, because they are different from society at large. The gay rights movement experiences the advantage of this kind of unity because of the construction of its subculture. It is primarily an urban subculture, but also a subculture in which gays in out-of-the-way places have access to a common cultural identification. A gay person on a farm in Iowa can have access to events and people in san Francisco primarily through an extensive gay press. Darsey (1991) states that, "This kind of transgeographical consciousness encourages references to the gay community as a national phenomenon and a corresponding mentality in which any threat is a threat to the whole" ( $p$. 48). 
What then is the effect, or connection of AIDS to the movement for gay rights? In the early 1980's as reports of a "gay cancer" were surfacing it was not clear how "rights" and "disease" would be linked. However, by 1983 AIDS and its associated sociopolitical threats began to color gay discourse. In fact, it is clear from many rhetorical examples that AIDS has changed what it means to be gay in the United states.

But Darsey (1991) is not alone in identifying the importance of considering the connection between the gay rights movement and the AIDS crisis. Gross (1991) states that:

The gay liberation movement emerged in the late 1960 's in the United States, spurred by examples of the black, anti-war, and feminist movements. Consequently, media attention to gay people and gay issues increased in the early 1970's ....culminating in 1973, with the decision by the American Psychiatric Association to delete homosexuality from its "official" list of mental diseases (p. 28).... By 1983 nearly all mass media attention to gay men was in the context of AIDSrelated stories.....AIDS moved up to the status of "front page" news after Rock Hudson emerged as the most famous person with AIDS. At present AIDS stories appear daily in print and broadcast news.... and the public image of gay men has been inescapably linked with the specter of plague. ( $p$. 30)

Treichler (1988) argues that the social dimension of the AIDS crisis is more pervasive in constructing our perceptions of the disease than are the biological dimensions of AIDS. In discussing the role of the gay subculture in creating the discourse and politics of AIDS, 
Treichler states that:

Almost from the beginning, members of the gay community, through intense interest and informed political activism, have repeatedly contested the terminology, meanings, and interpretations produced by scientific inquiry. Such contestations had occurred a decade earlier in the struggle over whether homosexuality was to be officially classified as an illness by the American Psychiatric Association. Gay men and lesbians in the succeeding period had achieved considerable success in political organizing. AIDS, then, first struck members of a relatively seasoned and politically sophisticated community. (p. 40$)$

Feldman (1990) claims that gay men were just coming out of a state of political oppression when the AIDS crisis began. Many Americans had stopped viewing gay's as sinners or criminals, and saw the gay community as a viable social alternative. The community had established its own identity through its businesses, publications, and social and political organizations. But with the arrival of AIDS, which may kill up to 20 percent of all gay men in the United states, gay's are again being pushed back into the margins.

There has also been concern in the gay community that the gains of gay liberation will be lost in the AIDS crisis. Some feel that gay's have done more to repress themselves than anyone outside the community (Rist, 1989). But others feel that gay's are not the cause of their own oppression and that the community must "challenge and alter the power relationships that define our possibilities," and that the AIDS crisis has lead many in the community to respond to "the realities of the health care system, insurance 
companies, state legislatures, a biased press, religious institutions, and various levels of government agencies" (Cagan, 1989, p. 14-15).

As I have established, the AIDS crisis in the United states is closely linked to the gay community. Additionally, gay people have a history of oppression that began long before AIDS. These facts can hardly be ignored in building a complete picture of how AIDS-related news is framed by the mainstream press. Many writers have stated that media coverage would have been different, or would be different today, if AIDS were not perceived as a gay disease (see Kinsella, 1989; Diamond, 1990; Shilts, 1988; Rouilard, 1991; Gallagher, 1991). But to answer the question, why was this frame, and not another used? I maintain that concept of hegemony must be examined.

\section{HEGEMONY AND THE PRESS}

Todd Gitlin (1980) interprets Antonio Gramsci's concept of hegemony as a ruling class's domination of subordinate classes and groups through the elaboration and penetration of ideology into their common sense and everyday practice. Hegemony, as Gitlin states, "is the systematic engineering of mass consent to the established order....hegemony is, in the end, a process that is entered into by both dominators and dominated" (p.253). Williams (1977) asserts that hegemony is constructed through social relations but may be 
unspoken and unconscious. Hegemony is not just the domination of members of society, it defines reality for society. Williams states that "hegemony is... a whole body of practices and expectations.... it is a lived system of meanings and values" (p.110).

Hegemony works to protect and further the interests of the dominant class. The dominant class in late 20 th century America is mostly male, mostly middle-aged, mostly white, mostly middle class, and mostly heterosexual (Gross, 1991). Within the concept of hegemony it is difficult for the dominant class to accept an ideological threat from the dominated class. This can clearly be seen in the framing of news about AIDS. If, as has been established, AIDS is perceived as a gay disease, and if gay people in general, or more specifically, the gay rights movement is seen as a threat to the dominant ideology then it stands to reason that reporting about AIDS will often trivialize and marginalize gay people. The mainstream presses tend to support the dominant class. As Gitlin (1980) states:

Through the everyday workings of journalism, largescale social conflict is imported into the news institution and reproduced there: reproduced, however, in terms derived from the dominant ideology. Discrepant statements about reality are acknowledged -- but muffled, softened, blurred, fragmented.... The news routines are skewed toward representing demands, individuals, and frames which do not fundamentally contradict the dominant hegemonic principles. (p. 271)

The two mainstream newspapers I refer to in the study, the New York Times and the oregonian are part of the 
apparatus that supports the dominant ideology of our culture. News reporters, editors, and news sources all represent differing views on what is said. In the end, someone in the news organization makes a decision about what will be presented and how it will be framed. The chosen frame may challenge or validate the dominant ideology. But ultimately the frame that is chosen will impact social consciousness and reflect hegemonic practices.

The concept of hegemony is not limited to domination but also includes the element of participation in domination by the dominated. For instance, gay people are clearly dominated by the mainstream in our society. It would seem that gays would organize and fight back. However, the majority of gay people support and depend on the mainstream culture in order to survive. A gay person with HIV or AIDS has a tough time of it if he does not support the capitalist apparatus (part of the dominant ideology) which includes mainstream medical care, mainstream drug research, mainstream government funding, and the possibility of validation by the mainstream media.

In sum, the question why was this frame, and not another used? can be partially answered in terms of the hegemonic process. The mainstream press, as part of cultural hegemony in the United states, plays a central role in shaping and reinforcing the dominant ideology. Gay people and, to a large extent, the AIDS crisis because of 
its association as a gay disease do not fit into the dominant ideology of our culture. News frames either consciously or unconsciously reflect the dominant ideology and at times trivialize, marginalize, or ignore significant aspects of gay's experience and the AIDS crisis.

\section{CONCLUSIONS}

This research focused on the reporting of four individuals and their experiences with HIV and AIDS. The results of this work form one point of view, a point of view which is influenced by my role as the rhetorical critic. My past experiences of reading both mainstream and alternative reports about the AIDS crisis combined with my experience with loved ones who have died from AIDS complications and who are living with AIDS, results in a point of view that does not always support the mainstream ideology on AIDS. There are certainly other valid perspectives of how AIDSrelated news is reported.

At the completion of this study I am able to see limitations that I did not see as I began. A rhetorical study which relies on the text of newspapers as its sole data source is limited by that text. I did not have the responsibility or the inclination, under the methodology of rhetorical criticism, to seek out more information from the reporters or editors of the newspapers I studied. I could not ask a reporter why he framed a story the way he did, and 
I could not observe the operation of a newspaper staff as they framed the news. Again, I was limited to the text. I did however, have the responsibility to interpret the data based on my training and experience. In interpreting the text I was also limited in my knowledge of the reporters' knowledge and experience. For instance, I could only assume that the reporters were knowledgeable enough to accurately report on the AIDS crisis. However, as I stated earlier, much of the text I used in this study was closer to soft news or commentary than it was to hard news reporting. Few of the stories I examined contained hard news. This research was also limited both by the small number of news sources I examined and by the short length of the study. Finally, I feel that the most profound limitation and/or opportunity for the rhetorical critic is the responsibility to interpret data based on what the critic thinks and feels. Based, in part, on my assertion of the importance of the critic's training, experience, and limitations I feel that this research identified examples of trivialization and marginalization in mainstream reporting related to the four individuals I studied. However, the limited scope of this study does not allow me to generalize my findings to other newspaper reporting about individuals with AIDS. In summarizing his research on the rhetoric of the gay rights movement, Darsey (1991) comments on the value of his work and its generalizablity: 
There are specific insights here into the rhetoric of the gay liberation movement; a large body of discourse has been characterized broadly to allow the making of summary statements. There are also tentative statements about the larger issues, statements that can be made with confidence only when we have enough comparable studies to allow generalization. (p. 62)

Perhaps at some level this research contributes to the theory building Darsey refers to.

This study also posits a connection between the social movement for gay rights and the AIDS crisis. Additionally, I attempted to illustrate the role of hegemony as it influences editorial decisions. simply reading the newspaper texts I used in the research would not support connections to the gay rights movement or to hegemonic practices. Support for these claims is based on my training in rhetorical criticism and, most importantly, on the valuable research I cite in this study.

Future research which compares mainstream and alternative reporting of AIDS-related news might consider the combination of several methodologies such as rhetorical criticism and qualitative analysis. This combination would allow the researcher to compare or support interpretation with interviews of the participants in news reporting. other research might include a continued study which examines reporting of Magic Johnson in the months following his announcement, or an examination of story placement as a frame. 


\section{REFERENCES}

BOOKS AND JOURNAL ARTICLES

Berube, A. (1988, Fall). Living with AIDS. outlook, pp. 9 -19 .

Boulard, G. (1989, March). Coping with AIDS coverage. Editor and Publisher, p. 16.

Bowen, S. P., \& Michal-Johnson, P. (1990). A rhetorical perspective for HIV education with black urban adolescents. Communication Research, 17, 848-860.

Brecher, E. M. (1988, March-April). Straight sex, AIDS, and the mixed-up press. Columbia Journalism Review, pp. 46-49.

Brock, B. L., Scott, R. L., \& Chesebro, J. W. (1989). Methods of rhetorical criticism: A twentieth century perspective. (3rd ed.). Detroit: Wayne state University Press.

Cagan, L. (1989, February). AIDS as apocalypse: The deadly costs of an obsession. Christopher street, pp. 14-15.

Cathcart, R. S. (1980). Defining social movements by their rhetorical form. The Central states Speech Journal, $31,267-273$.

Cline, R. J. W., Freeman, K. E., \& Johnson, S. J. (1990). Talk among sexual partners about AIDS: Factors differentiating those who talk from those who do not. Communication Research, 17, 792-808.

Couturie, B., Epstein, R., \& Friedman, J. (Producers), Epstein, R., \& Freidman, J. (Directors). (1989). Common threads: Stories from the quilt [Film]. San Francisco: Telling Pictures.

Darsey, J. (1991). From "gay is good" to the scourge of AIDS: The evolution of gay liberation rhetoric, 19771990. Communication Studies, 42(1), 43-66. 
De witt, K. (1991, May 26). U. S. won't allow entry after all to people infected with AIDS virus. The oregonian, p. 17 .

Diamond, E. (1990, April). Covering AIDS in the nineties. New York, pp. $12,14$.

Dorfman, R. (1987, November). AIDS coverage: A mirror of society. The Quill, pp. 16-17.

Drushel, B. E. (1991). Sensationalism or sensitivity: Use of words in stories on Acquired Immune Deficiency Syndrome (AIDS by Associated Press Videotext. In M. A. wolf \& A. P. Kielwasser (Eds.), Gay people, sex, and the media (pp.47-61). London: Harrington Park Press.

Feldman, D.A. (Ed.) - (1990). Culture and AIDS. New York: Praeger.

Foss, S. K. (1989). Rhetorical criticism: Exploration and practice. Prospect Heights, IL: Waveland Press.

Gallagher, J. (1991, December 9). Johnson disclosure brings AIDS issues of middle America. The Advocate, pp. 1416 .

Gans, H. J. (1979). Deciding what's news. New York: Pantheon.

Gilder, E. (1989). The process of political praxis: Efforts of the gay community to transform the social signification of AIDS. Communication Quarterly, 37 , 27-38.

Gitlin, T. (1980). The whole world is watching: Mass media in the making and unmaking of the new left. Berkeley, CA: University of California Press.

Gitlin, T. (1987). Television's Screens: Hegemony in transition. In D. Lazere (Ed.), American media and mass culture (p. 241). Berkeley, CA: University of California Press.

Gross, L. (1991). Gays, lesbians, and popular culture. In M. A. Wolf \& A. P. Kielwasser (Eds.), Gay people, sex, and the media, (pp. 19-46). London: Harrington Park Press.

Grube, A., \& Boehme-Duerr, K. (1988). AIDS in international news magazines. Journalism Quarterly, 65, 686-689. 
House oks bathhouse closure bill. (1985, october 3 ). The oregonian, p. 16 .

Jamieson, K. H., \& Campbell, K. K. (1988). The interplay of influence (2nd ed.). Belmont, CA: Wadsworth.

Juengst, E. T., \& Koenig, B. A. (Eds.), (1989). The meaning of AIDS. New York: Praeger.

Kinsella, J. (1989). Covering the plaque: AIDS and the American media. New Brunswick, NJ: Rutgers University Press.

Kramer, S. D. (1988, March). The Media and AIDS. Editor and Publisher, pp. 10-43.

Lazere, D. (Ed.). (1987). American media and mass culture. Berkeley, CA: University of California Press.

Leishman, K. (1989, March). The outsider. Rolling stone, pp. $75,186$.

Lucas, S. E. (1980). Coming to terms with movement studies. The Central states Speech Journal, 31, 255-266.

Mccuen, G. E. (Ed.). (1987). The AIDS crisis: Conflicting social values. Hudson, WI: McCuen.

Mumby, D. K. (1988). Communication and power in organizations: Discourse, ideology, and domination. Norwood, NJ: Ablex.

Nelson, J. (1981). Media reaction to the 1979 gay march on Washington. In J. W. Chesebro (Ed.), Gayspeak: Gay male and lesbian communication (pp. 189-196). New York: Pilgrim Press.

Norton, R. (1990). The communication scholar in the AIDS crisis. Communication Research, 17, 733-742.

Panem, S. (1988). The AIDS bureaucracy. Cambridge, MA: Harvard University Press.

Ris, D. Y. (1989), February). AIDS as apocalypse: the deadly costs of an obsession. Christopher street, $p$. 13 .

Scheerhorn, D. (1990). Hemophilia in the days of AIDS: Communicative tensions surrounding "associated stigmas." Communication Research, 17, 842-847. 
Shilts, R. (1988). And the band played on: Politics, people, and the AIDS epidemic. New York: Penguin.

Smith, R. L. (1991, July). More than "Just a disease." Christopher street, pp. 12-15.

Sontag, S. (1989) - AIDS and its metaphors. Toronto: Collins.

Stein, M. L. (1988, May). Advice on AIDS coverage. Editor and Publisher, p. 45.

stewart, C. J. (1980). A functional approach to the rhetoric of social movements. The Central states Speech Journal, 31, 298-305.

Stroman, C. A., \& Seltzer, R. (1989). Mass media and knowledge of AIDS. Journalism Quarterly, 66, 881-887.

Taylor, C. (1990). AIDS and the pathodenesis of metaphor. In D.A. Feldman (Ed), Culture and AIDS (p. 55). New York: Praeger.

Treichler, P. A. (1988). AIDS, homophobia, and biomedical discourse: An epidemic of signification. In D. Crimp (Ed.), AIDS: Cultural analysis/cultural activism (pp. 31-70). Cambridge, MA: MIT Press.

Tuchman, G. (1978). Making News: A study in the construction of reality. New York: Free Press.

Williams, R. (1977). Marxism and literature. Oxford: oxford University Press.

NEWS STORIES GROUPED BY MEDIA SOURCE

The New York Times

AIDS protesters-as-Santas at Macy's (1991, November 30, The New York Times, p. 22.

Altman, L.K. (1985, July 30). Search for an AIDS drug is case history in frustration. The New York Times, sec. 3 , pp. 1, 10 .

Berger, J. (1985, October 3). Rock Hudson, screen idol, dies at 59. The New York Times, p. D23. 
Eckholm, E. (1991, November 17). More than inspiration is needed to fight AIDS. The New York Times, sec 4, pp. 1,3 .

Gooodman, W. (1991, November 17). The story TV can't resist. The New York Times, p. 31 .

Harmetz, A. (1985, August 8). Old and new Hollywood seen in attitude to AIDS. The New York Times, p. C15.

Hudson has AIDS, spokesman says. (1985, July 26). The New York Times, p. C3.

Klass, P. (1991, August 18). Frescoes, tote bags and T-cells. The New York Times, pp. 24-26.

Kolata, G. (1991, November 7). Path from infection to illness. The New York Times, p. B15.

Lambert, B. (1991, December 9). Kimberly Bergallis is dead of AIDS at 23. The New York Times, p. D9.

Margolick, D. (1991, August 29). Man wih AIDS virus sues to be a Macy's Santa again. The New York Times, p. B1.

Martin, D. (1991, December 21). Santa wih AIDS spreads Cheer. The New York Times, p. 22.

New York day by day. (1985, July 27). The New York Times, p. 26 .

Rock Judson is ill wih liver cancer in Paris hospital. (1985), July 24). The New York Times, sec 3, p. 16 .

Shilts, R. (1991, December 10). Good AIDS, bad AIDS. The New York Times, p. 31 .

Spencer, M. (1991, November 8). A lesson from a special hero. The New York Times, p. B15.

Stevenson, R.W. (1991, November 9). Magic Johnson ends his career, saying he has AIDS infection. The New York

Times, pp. 1, B14.

Vacsey, G. (1991, November 10). The plague finally reaches the box scores. The New York Times, p. 30 .

The Oregonian

Benke, R. (1985, October 3). Rock Hudson Dies of Aids. The Oregonian, p. 1 . 
Clary M. (1991, December 9). Kimberly Bergalis dies of AIDS at age 23. The Oregonian, p. 1-15.

Frei, T. (1991, December 9). Johnson may be quitting basketball, but he's not running away. The oregonian, p. B2.

House OKs bathhouse closure bill. (1985, october 3 ). The oregonian, p. 16 .

Manning, S. (1985, october 3). Celebrities laud Hudson's courage. The oregonian, p. 16.

Shilts, R. (1991, November 9). AIDS activists hope Magic sparks action against disease. The oregonian, from The San Francisco Chronicle, pp. B1, B3.

Thackarey. T. (1985, October 3). Hudson carryover from old Hollywood star system. The oregonian, p. 16.

The Advocate

Creative sorts. (1991, December 17). The Advocate, p. 10. Daniels M. (1985, September 3). Mediawatch. The Advocate, pp. $22-23$.

Gallagher. J. (1991, september 10). The age of AIDS hysteria. The Advocate, pp. 34-37.

Gallagher, J. (1991, December 17). Johnson disclosure brings AIDS issues to middle America. The Advocate. pp. 14-16.

Rock Hudson has AIDS. (1985, August 20). The Advocate. p. 22.

Rothman, P. (1991, December 31). Could it be Magic [Letter to the editorl? The Advocate, p. 13 .

Roullard, R. (1991, December 17). Therefore, Magic owes us? The Advocate, pp. 8-9.

Christopher street

Bockman, P. (1992, January 6). Mr. Bockman writes. Christopher street, pp. 16-17.

Hadleigh. B. (1987, February). A conversation wih Rock Hudson. Christopher street, pp. 12-15. 
Smith, R.I. (1991, July). More than "Just a disease." Christopher street, pp. 12-16.

The Bay Area Reporter

Botkin, M.C. (1991, November 21). The HIVer glossary, part III. The Bay Area Reporter. p. 23.

Conkin, D. (1991, November 21). Would-be HIV-positive Santa sues Macy's over job bias. The Bay Area Reporter, p. 20 .

\section{The New York Native}

Hammond, J. (1991, November 25). Massacre on 34th street:

HIV fear deprives santa of a job. The New York Native, p. 8 . 